\title{
OPEN Akkermansia muciniphila uses human milk oligosaccharides to thrive in the early life conditions in vitro
}

\author{
loannis Kostopoulos ${ }^{1}$, Janneke Elzinga ${ }^{1}$, Noora Ottman ${ }^{1}$, Jay T. Klievink ${ }^{4}$, \\ Bernadet Blijenberg ${ }^{3}$, Steven Aalvink ${ }^{1}$, Sjef Boeren ${ }^{2}$, Marko Mank ${ }^{3}$, Jan $\mathrm{Knol}^{1,3}$, \\ Willem M. de $\operatorname{Vos}^{1,4}$ \& Clara Belzer ${ }^{1 \bowtie}$
}

\begin{abstract}
Akkermansia muciniphila is a well-studied anaerobic bacterium specialized in mucus degradation and associated with human health. Because of the structural resemblance of mucus glycans and free human milk oligosaccharides (HMOs), we studied the ability of $A$. muciniphila to utilize human milk oligosaccharides. We found that $A$. muciniphila was able to grow on human milk and degrade HMOs. Analyses of the proteome of $A$. muciniphila indicated that key-glycan degrading enzymes were expressed when the bacterium was grown on human milk. Our results display the functionality of the key-glycan degrading enzymes ( $\alpha$-L-fucosidases, $\beta$-galactosidases, exo- $\alpha$-sialidases and $\beta$-acetylhexosaminidases) to degrade the HMO-structures 2'-FL, LNT, lactose, and LNT2. The hydrolysation of the host-derived glycan structures allows $A$. muciniphila to promote syntrophy with other beneficial bacteria, contributing in that way to a microbial ecological network in the gut. Thus, the capacity of $A$. muciniphila to utilize human milk will enable its survival in the early life intestine and colonization of the mucosal layer in early life, warranting later life mucosal and metabolic health.
\end{abstract}

Akkermansia muciniphila is a Gram-negative anaerobe, belonging to the phylum Verrucomicrobia ${ }^{1}$, that colonizes the mucus layer of the human gastrointestinal (GI) $\operatorname{tract}^{2}$. A. muciniphila is associated with a healthy mucosal layer and metabolic state as it has been inversely correlated with obesity ${ }^{3,4}$, metabolic diseases (Type 2 diabetes) ${ }^{5}$ as well as intestinal disorders (inflammatory bowel disease (IBD) and appendicitis) ${ }^{6-8}$. This intestinal bacterium has an extraordinary capacity to degrade mucin as the sole energy, carbon and nitrogen source and convert this polymer into mostly acetate and propionate ${ }^{2}$.

Akkermansia muciniphila is a common member of the adult and infant microbiota ${ }^{9}$. The infant's gut colonisation with A. muciniphila has been detected from the first month of life, with a continuously increasing abundance during adulthood ${ }^{9,10}$. Additionally, A. muciniphila was detected in the breast tissue of lactating mothers as well as in human milk ${ }^{11-13}$. Interestingly, two studies have reported that $A$. muciniphila was found to be lower in abundance in the breast-fed infants compared to formula-fed infants ${ }^{14,15}$. In a more recent study with 98 Swedish infants though, the abundance and the prevalence of $A$. muciniphila increased between 4 and 12 months old, and showed no significant change depending on delivery mode or type of feeding ${ }^{16}$. Early in life, mother's milk is often the only source of nutrients and dietary glycans for infants, and it is considered the best nourishment for the development of the new-born ${ }^{17}$. The glycans in human milk are named human milk oligosaccharides (HMOs), and they have proven to have an impact on infant intestinal microbiota composition ${ }^{18}$. Human milk contains 5-15 g/l HMOs, with more than 200 different HMO structures reported of which 100 have been successfully elucidated ${ }^{19-22}$. The presence and the quantity of these HMOs structures vary per individual and are related to the genetic Secretor and Lewis status of the mother ${ }^{23}$. The major building blocks of monosaccharides present in HMOs are D-glucose (Glc), D-galactose (Gal), $N$-acetyl-glucosamine (GlcNAc), L-fucose (Fuc), and

${ }^{1}$ Laboratory of Microbiology, Wageningen University, Stippeneng 4, 6708 WE Wageningen, The Netherlands. 'Laboratory of Biochemistry, Wageningen University, Stippeneng 4, 6708 WE Wageningen, The Netherlands. ${ }^{3}$ Danone Nutricia Research, Uppsalalaan 12, 3584 CT Utrecht, The Netherlands. ${ }^{4}$ Human Microbiome Research Program, Faculty of Medicine, University of Helsinki, P.O. Box 66, 0014 Helsinki, Finland. ${ }^{\square}$ email: clara.belzer@wur.nl 

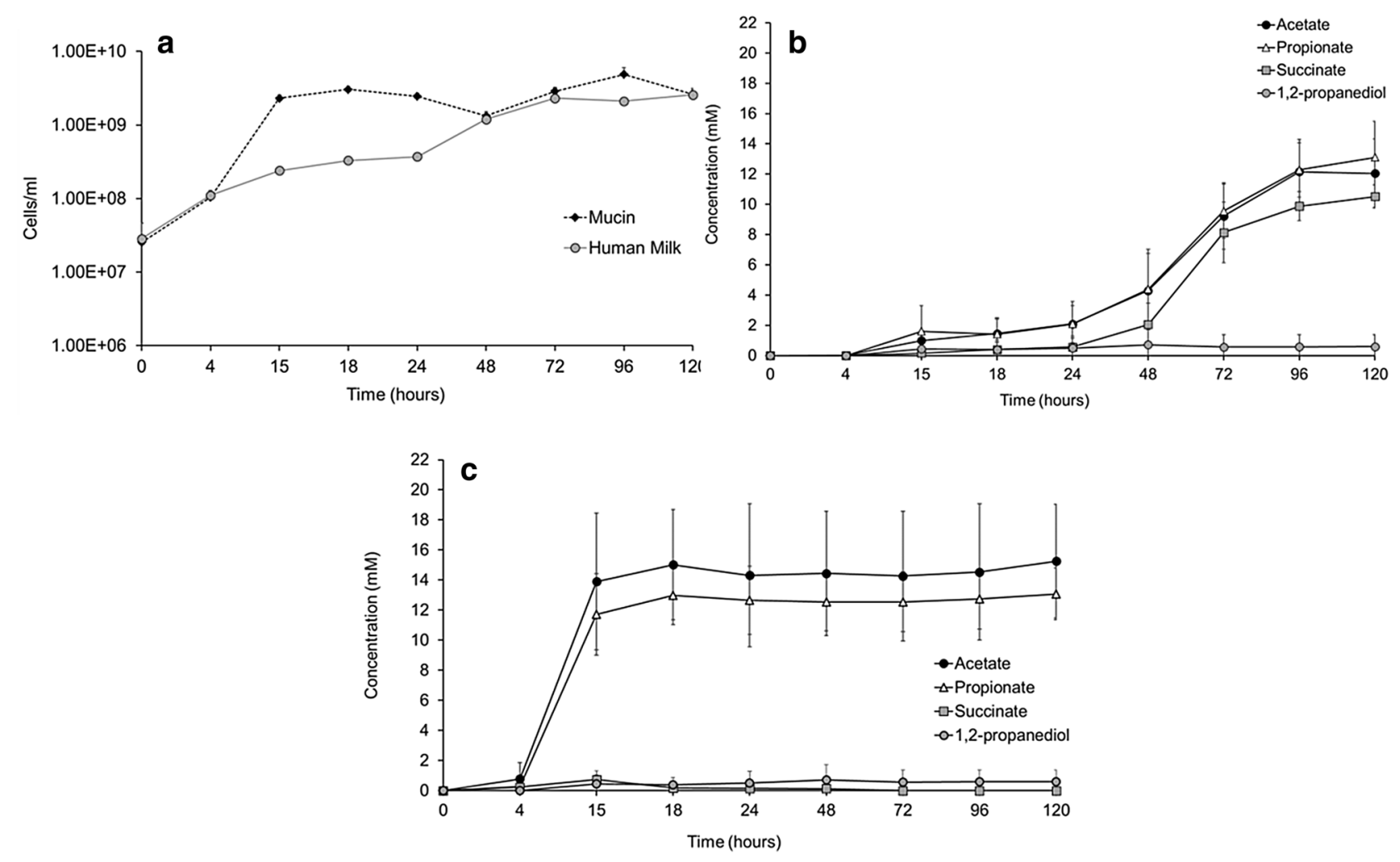

Figure 1. A. muciniphila growth in human milk. (a) A. muciniphila growth in human milk or porcine mucin as the sole carbon and nitrogen source. Error bars indicate the standard error of qPCR for three biological replicates. A. muciniphila SCFAs production (b) in human milk and (c) in mucin. Error bars indicate the standard deviation of three biological replicates.

$\mathrm{N}$-acetylneuraminic acid (sialic acid, Neu5Ac) ${ }^{24}$. These sugars form a number of complex glycans containing well-defined different glycosidic linkages resulting in both linear and branched structures ${ }^{25}$. In human milk $70 \%$ of the oligosaccharides are fucosylated and $30 \%$ are sialylated ${ }^{19,26}$. HMOs can function as prebiotic substrates by promoting and stimulating the growth of beneficial bacteria such as bifidobacteria ${ }^{27}$. Nowadays, supplementation of infant formulae with HMOs, such as 2'-FL and LNnT, is gaining more and more interest to bring infant formula composition even closer to human milk $^{28}$. In addition, some of these oligosaccharide molecules inhibit the colonisation of pathogenic bacteria by acting as receptor analogues and binding to the bacterial surface $e^{24}$.

The resemblance of glycosidic structure between HMOs and mucin glycans might explain why some bacteria are capable of utilising both human milk glycans and host mucosal glycans (mucins) ${ }^{29,30}$. Mucins are the main structural components of the mucus layer that covers the gut epithelium surface. Mucins' protein core consists of $80 \%$ carbohydrates, mainly $N$-acetylgalactosamine, $N$-acetylglucosamine, fucose, galactose and sialic acid ${ }^{31,32}$. The mucus layer in the human gut is divided into an outer layer, which provides a nutrient-rich habitat for the microbiota, and an inner layer, which is firmly attached to the surface of the epithelium and virtually free of bacteria $^{33}$. In the human gut, $A$. muciniphila has the extraordinary capacity to degrade mucins by employing a large arsenal of sulfatases and glycoside hydrolases (GH) for effective metabolism of mucin glycans such as $\alpha$-fucosidases, $\alpha$-sialidases, $\beta$-galactosidases, $\beta$-acetylhexosaminidases, and $\alpha$-acetylglucosaminidases ${ }^{1,34}$.

We hypothesize that the presence of $A$. muciniphila in the early life intestine is the result of its ability to use its mucin degrading machinery to breakdown HMOs. Its presence in the early life intestine will enhance microbial ecologic network formation and healthy microbial colonisation of the mucosal layer warranting later life health. To assess this, we tested the ability of $A$. muciniphila to grow on human milk and different HMOs. Subsequently, we identified the HMOs structures that A. muciniphila was able to break down and the enzymes responsible for the degradation.

\section{Results}

A. muciniphila grows on human milk via HMOs utilisation. Incubation of $A$. muciniphila on human milk resulted in growth (Fig. 1a). The fermentation profile of the cultures showed production of acetate, propionate, and succinate (Fig. 1b,c) as well as release of glucose and galactose due to the utilisation of the lactose that is already present in the breast milk and in the HMOs (Fig. 2a). The amounts of produced short-chain fatty acids (SCFAs) and utilised sugars are shown in the Supplementary Table 2. We next sought to investigate which HMOs structures were utilised by A. muciniphila during the growth on human milk. The HMOs profile showed utilisation of neutral trioses ( 2 '-fucosyllactose [2'-FL] and 3-fucosyllactose [3-FL]), tetraoses (difucosyllactose [DFL], lacto- $N$-tetraose [LNT], lacto- $N$-neotetraose [LNnT]), pentaoses (lacto-fucopentaose I [LNFP I], 

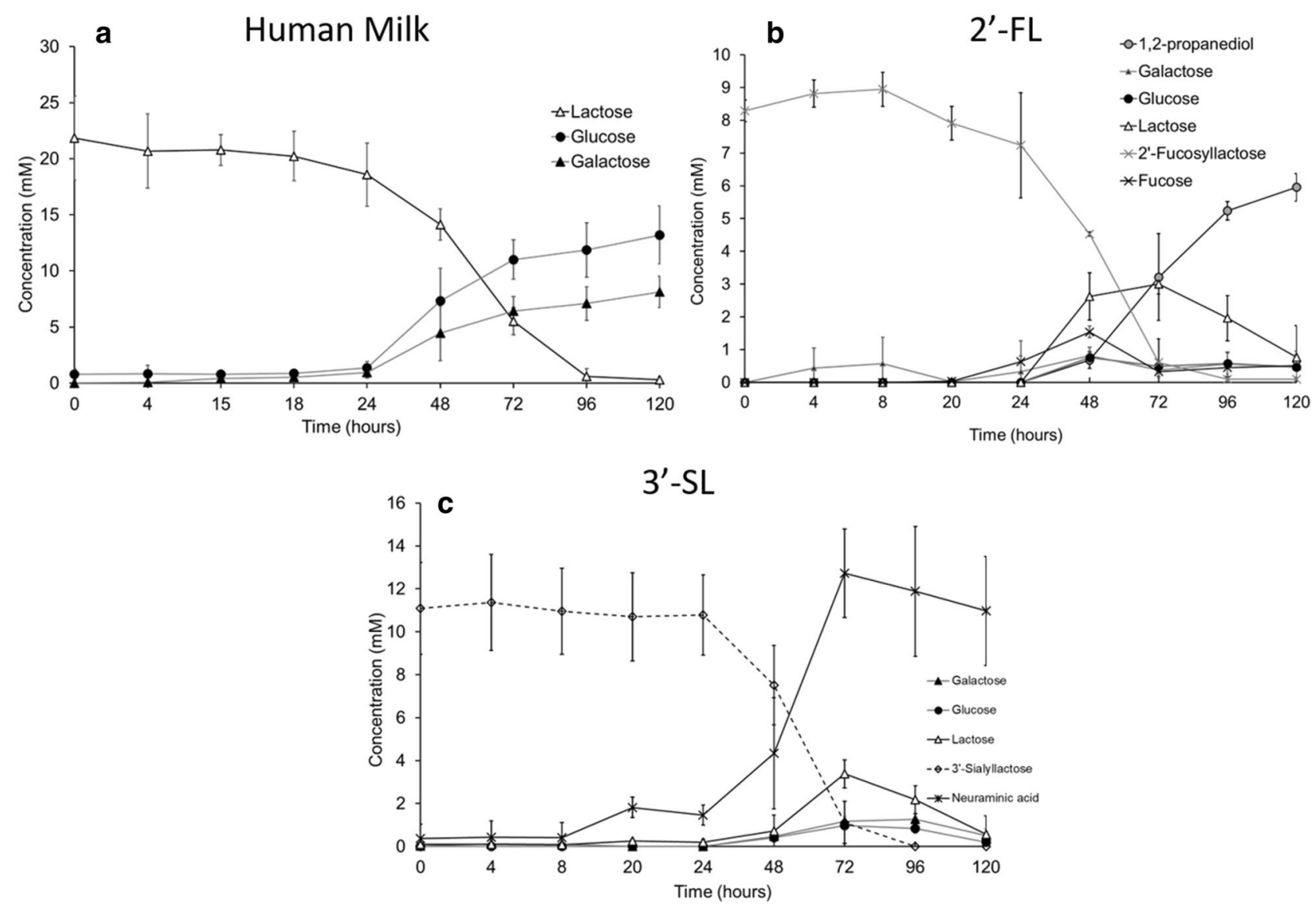

Figure 2. A. muciniphila HMO degradation. (a) Human Milk, (b) 2'-fucosyllactose (2'-FL), and (c) $3^{\prime}$-sialyllactose (3'-SL). Error bars represent the standard deviation of three biological replicates.

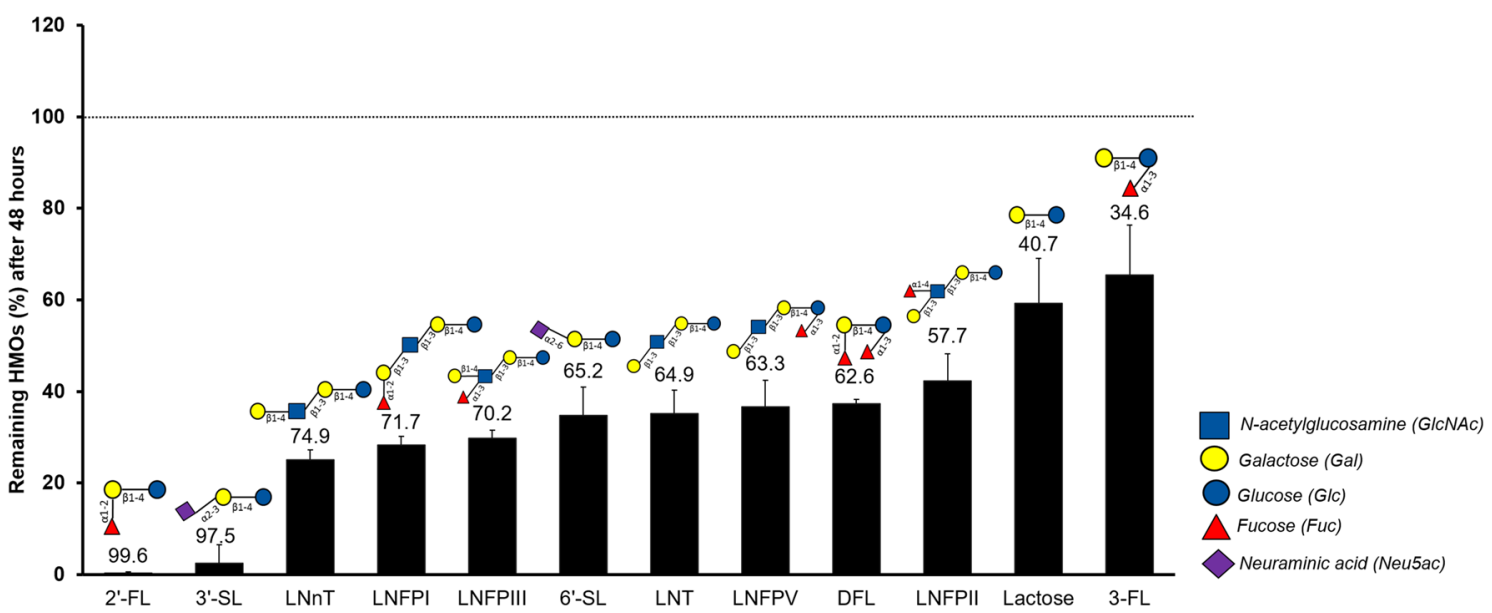

Figure 3. Utilisation of HMOs structures by A. muciniphila incubated in $10 \%$ human milk. The numbers above each bar indicate the degradation percentage of each HMO. Error bars represent the error propagation of three biological replicates.

lacto-fucopentaose II [LNFP II], lacto-fucopentaose III [LNFP III], lacto-fucopentaose V [LNFP V]), and acidic trioses (3'-siallylactose [3'-SL], 6'-sialyllactose [6'-SL]) (Fig. 3). All measured HMOs were reduced at least twofold (Fig. 3). The HMO profile analysis revealed that A. muciniphila utilises almost completely $2^{\prime}$-FL and 3 '-SL present in human milk (99.65\% and $97.49 \%$, respectively) (Fig. 3).

Next, it was tested whether these nutritional components by themselves could promote the growth of $A$. muciniphila. Incubation of A. muciniphila with pure 2'-FL or $3^{\prime}-\mathrm{SL}(10 \mathrm{mM})$ resulted in growth (Supplementary Fig. 1) and demonstrated the release of lactose from both $2^{\prime}$-FL or $3^{\prime}-S L$ (Fig. 2b,c). The resulting lactose was further broken down to its monosaccharides (glucose and galactose). Growth on 2'-FL resulted in the production 
of 1,2-propanediol $(5.95 \pm 0.42 \mathrm{mM})$, which is an indication of the fucose metabolism by A. muciniphila. The liberated neuraminic acid from 3'-SL was not further catabolised by the bacterium. The overall fermentation efficiency was determined by calculating the carbon balance; the recovery of carbon atoms at $48 \mathrm{~h}$ of $2^{\prime}$-FL and 3'-SL was 86.58 and $82.58 \%$ respectively (Supplementary Table 3a). Furthermore, the amounts of produced short-chain fatty acids (SCFAs) and utilised sugars of $A$. muciniphila grown in 2'-FL and 3 '-SL are shown in the Supplementary Table $3 \mathrm{~b}$.

A. muciniphila exhibits glycoside hydrolase expression during growth on human milk. We performed proteomic analysis on the A. muciniphila cultures grown on human milk to identify the active enzymes that could contribute to the degradation of human milk and its components. A total of 832 bacterial proteins were detected after growth on human milk. We mined the proteome data for proteins predicted to participate in carbohydrate metabolism and this returned 109 proteins and over half of them (62 proteins) are primarily involved in this specific metabolic pathway (Table 1). A. muciniphila possesses 58 proteins that encode for glycoside hydrolases (GHs). In our results, we detected $43 \mathrm{GHs}$ and 19 of these proteins belong to the six GH families (GH2, GH20, GH29, GH33, GH35 and GH95) that target the most common linkages found within HMOs. We identified four $\beta$-galactosidases that belong to GH2 family, two GH35 $\beta$-galactosidases, seven $\beta$-hexosaminidases from GH family 20 , two GH29 $\alpha$-fucosidases, two GH95 $\alpha$-fucosidases and two exo-alpha sialidases from GH33 (Table 1). Therefore, we proposed A. muciniphila employed the fucosidases to release the terminal $\alpha 1-2 / 3 / 4$ linked fucose from the fucosylated HMOs; 2'-FL (Fucal-2Gal $\beta 1-4 \mathrm{Glc}$ ), 3-FL (Gal $\beta 1$ 4Fuca1-3Glc), DFL (Fuca1-2Gal $\beta 1-4$ Fuca1-3Glc), LNFPI (Fuca1-2Gal $\beta 1-3 G l c N A c \beta 1-3 G a l \beta 1-4 G l c)$, LNFP II (Gal $\beta 1$-3Fuca1-4GlcNAc $\beta 1-3 \mathrm{Gal} \beta 1-4 \mathrm{Glc}$ ), LNFP III (Gal $\beta 1-4$ Fuca1-3GlcNAc $\beta 1-3 \mathrm{Gal} \beta 1-4 \mathrm{Glc}$ ) and LNFP V (Gal $\beta 1$-3GlcNAc $\beta 1-3 \mathrm{Gal} \beta 1-4 \mathrm{Fuc} \alpha 1-3 \mathrm{Glc})$. Additionally, A. muciniphila expressed the 2 sialidases that can liberate the $\alpha 2-3$ and $\alpha 2-6$ linked sialic acid from the sialylated glycans $3^{\prime}$-SL (Neu5Aca2-3Gal $\beta 1-4 \mathrm{Glc}$ ) and 6'-SL (Neu5Aca2-6Gal $\beta 1-4 \mathrm{Glc}$ ) present in the human milk. Furthermore, the hydrolysis of the terminal $\beta 1-3$ and $\beta 1-4$ galactose residues found in the HMOs structures; LNT (Gal $\beta 1-3 \mathrm{GlcNAc} \beta 1-3 \mathrm{Gal} \beta 1-4 \mathrm{Glc})$, LNnT (Gal $\beta 1$ $4 \mathrm{GlcNAc} \beta 1-3 \mathrm{Gal} \beta 1-4 \mathrm{Glc})$, lactose (Gal $\beta 1-4 \mathrm{Glc})$, as well as LNFP II, LNFP III and LNFP V can be the result of $\beta$-galactosidases' action expressed by $A$. muciniphila during growth on human milk. A. muciniphila expressed also $7 \beta$-hexosaminidases which are responsible for releasing the terminal $\beta 1-3$ and $\beta 1-4 N$-acetylglucosamine (GlcNAc) bound to glycan structures. However, GlcNAc is usually found as terminal sugar in HMO glycans but rather is often decorated by other monosaccharides (galactose, fucose, sialic acid). Thus, A. muciniphila might use its hexosaminidases to degrade simpler HMOs such as Lacto- $N$-biose (Gal $\beta 1$-3GlcNAc), LNT2 (GlcNAc $\beta 1$ $3 \mathrm{Gal} \beta 1-4 \mathrm{Glc})$. In addition, $A$. muciniphila expressed some of the necessary enzymes to metabolise the liberated monosaccharides from the HMOs degradation. A. muciniphila employs, for example, Amuc_1833 (L-fucose transporter-fucP), Amuc_1832 (L-fucose isomerase-fucI), Amuc_1830 (L-fuculokinase-fucK), and Amuc_1829 (class II aldolase-fucA) for the utilisation of the liberated fucose to 1,2-propanediol. Furthermore, Amuc_0969 (Galactokinase) participates in the first steps of the galactose metabolism by converting the free galactose into a-D-galactose-1-phosphate, while Amuc_0097 (ROK family protein) can be used by A. muciniphila to convert glucose to $\alpha$-D-glucose-6-phosphate during the first step of the glycolysis pathway (Supplementary Table 4). Nevertheless, A. muciniphila lacks all the necessary enzymes for the sialic acid utilisation, since no expression of these enzymes was observed in the proteome data. These data demonstrate that $A$. muciniphila has the enzymatic capacity to utilise a broad range of HMOs as well as their constituents.

Characterization of $\boldsymbol{A}$. muciniphila HMO degrading enzymes. The next step of the study was concerned with the characterisation of $A$. muciniphila enzymes that are effective in HMO-degradation. Therefore, we assessed five glycan-degrading enzymes identified by proteomics that are also predicted to hydrolyse the glycosidic bonds of lactose and the HMOs; 2'-FL, LNT and LNT2 (Table 1); one $\alpha$-fucosidase (Amuc_0010), two $\beta$-galactosidases (Amuc_0771 and Amuc_1686) and two $\beta$-acetylhexosaminidases (Amuc_0369 and Amuc_2136). The enzymatic activity of the recombinant proteins was first assessed using synthetic substrates (Table 2). Amuc_0771 and Amuc_2136 showed a pH optimum of 5.0, while Amuc_0010 and Amuc_0369 displayed optimal $\mathrm{pH}$ at 5.6. For Amuc_1686 the rate of $\mathrm{pNP}$ release $\left(\mu \mathrm{M} \mathrm{min}{ }^{-1}\right)$ was similar for all the different $\mathrm{pH}$ values that were tested (Supplementary Fig. 2). $\mathrm{pH} 5.0$ was selected as the optimal pH for this enzyme. Each enzyme's optimal $\mathrm{pH}$ and temperature of $37^{\circ} \mathrm{C}$ were used to assess the kinetic parameters of these proteins against synthetic substrates pNP- $\alpha-\mathrm{L}-\mathrm{Fuc}, \mathrm{pNPG}$ and GlcNAc- $\beta$-pNP (Table 2 and Supplementary Fig. 3 ). The $\alpha$-L-fucosidase (Amuc_0010) showed a $K_{\mathrm{M}} 839 \pm 46.72 \mu \mathrm{M}$ against pNP-Fucose. Both $\beta$-acetylhexosaminidases (Amuc_0369 and Amuc_2136) exhibited hexosaminidase activity by cleaving GlcNAc from pNP-GlcNAc. A lower $\bar{K}_{\mathrm{M}}$ for Amuc_0369 $(322.37 \pm 43.64 \mu \mathrm{M})$ was observed than Amuc_2136 $(714.55 \pm 47.96 \mu \mathrm{M})$. Cleavage of galactose from pNPG was detected with $\beta$-galactosidases (Amuc_0771 and Amuc_1686). Amuc_0771 showed higher $K_{\mathrm{M}}(2,599 \pm 565.27 \mu \mathrm{M})$ than Amuc_1686 $(319.40 \pm 259.30 \mu \mathrm{M})$. The ability of the $\alpha$-L-fucosidase (Amuc_0100) for cleaving a1-2 linked fucose from 2'-FL (Fuca1-2Galß1-4Glc) was assessed (Table 2 and Supplementary Fig. 4). The enzyme exhibited a high $K_{\mathrm{M}}$ and lower activity $\left(152.08 \mathrm{~min}^{-1} k_{\text {cat }}\right)$ against $2^{\prime}$-FL than pNP-Fuc $\left(2.27 \times 10^{4} \mathrm{~min}^{-1} k_{\text {cat }}\right)$. The activity of $\beta$-acetylhexosaminidases (Amuc_0369 and Amuc_2136) on the HMOs, LNT (Gal $\beta 1-3 \mathrm{GlcNAc} \beta 1-3 \mathrm{Gal} \beta 1-4 \mathrm{Glc}$ ) and LNT2 (GlcNAc $\beta 1-3 \mathrm{Gal} \beta 1-4 \mathrm{Glc})$ was assessed as well. The substrate and product specificity were monitored by HPAEC-PAD. For both enzymes no liberation of GlcNAc was observed in the presence of LNT, while both A. muciniphila $\beta$-acetylhexosaminidases were able to cleave the terminal GlcNAc off lactose resulting in LNT2. Amuc_0369 exhibited a $k_{\text {cat }} 1.42 \times 10^{4} \mathrm{~min}^{-1}$ and a $K_{\mathrm{M}} 3,980 \pm 210.30 \mu \mathrm{M}$ against LNT2. Amuc_2136 showed higher substrate affinity than Amuc_0369 $\left(2,435.82 \pm 289.51 \mu \mathrm{M} K_{\mathrm{M}}\right)$ but no significant difference in the catalytic activity $\left(1.45 \times 10^{4} \mathrm{~min}^{-1} k_{\text {cat }}\right)$. The $\beta$-galactosidases (Amuc_0771 and Amuc_1686) were tested for their capability to break down galactosidic link- 


\begin{tabular}{|c|c|c|c|c|c|}
\hline CAZy & Locus tag & Protein & $\begin{array}{c}\text { Average_LFQ_ } \\
\text { Human Milk }\end{array}$ & KO ID & Pathway \\
\hline GH20 & Amuc_2136 & $\begin{array}{l}\text { Glycoside hydrolase, } \\
\text { family } 20 \text {, catalytic core }\end{array}$ & 8.64 & ko00511;ko00520 & $\begin{array}{l}\text { Other glycan degradation; } \\
\text { Amino sugar and } \\
\text { nucleotide sugar } \\
\text { metabolism }\end{array}$ \\
\hline $\mathrm{GH} 2$ & Amuc_0824 & $\begin{array}{l}\text { Glycoside hydrolase family } \\
2 \text { TIM barrel }\end{array}$ & 8.55 & ko00052;ko00511 & $\begin{array}{l}\text { Galactose metabolism; } \\
\text { Other glycan degradation }\end{array}$ \\
\hline $\mathrm{GH} 2$ & Amuc_0290 & $\begin{array}{l}\text { Glycoside hydrolase family } \\
2 \text { sugar binding }\end{array}$ & 8.43 & ko0005 2;ko00511 & $\begin{array}{l}\text { Galactose metabolism; } \\
\text { Other glycan degradation }\end{array}$ \\
\hline GT35 & Amuc_0235 & $\begin{array}{l}\text { Alpha-glucan } \\
\text { phosphorylase }\end{array}$ & 8.42 & ko00500 & $\begin{array}{l}\text { Starch and sucrose } \\
\text { metabolism }\end{array}$ \\
\hline GH29 & Amuc_0392 & $\begin{array}{l}\text { Coagulation factor } 5 / 8 \text { type } \\
\text { domain protein }\end{array}$ & 8.23 & ko00511 & Other glycan degradation \\
\hline \multirow[t]{2}{*}{ CE11 } & Amuc_1918 & $\begin{array}{l}\text { Beta-hydroxyacyl-(Acyl- } \\
\text { carrier-protein) } \\
\text { dehydratase FabZ }\end{array}$ & 8.21 & ko00061;ko00540 & \\
\hline & Amuc_0155 & $\begin{array}{l}\text { Phosphoglucomutase/phos } \\
\text { phomannomutase } \\
\text { alpha/beta/alpha domain I }\end{array}$ & 8.19 & ko00051;ko00520 & $\begin{array}{l}\text { Fructose and mannose } \\
\text { metabolism; Amino sugar } \\
\text { and nucleotide sugar } \\
\text { metabolism }\end{array}$ \\
\hline GH31 & Amuc_1008 & $\begin{array}{l}\text { Glycoside hydrolase family } \\
31\end{array}$ & 8.16 & & \\
\hline GH109 & Amuc_0017 & $\begin{array}{l}\text { Glycosyl hydrolase family } \\
109 \text { protein } 1\end{array}$ & 8.14 & & \\
\hline GH84 & Amuc_0052 & $\begin{array}{l}\text { Hyalurononglucosaminidas } \\
\mathrm{e}\end{array}$ & 8.09 & ko00531 & $\begin{array}{l}\text { Glycosaminoglycan } \\
\text { degradation }\end{array}$ \\
\hline CE9 & Amuc_0948 & $\begin{array}{l}\text { N-acetylglucosamine-6- } \\
\text { phosphate deacetylase }\end{array}$ & 7.84 & ko00520 & $\begin{array}{l}\text { Amino sugar and } \\
\text { nucleotide sugar } \\
\text { metabolism }\end{array}$ \\
\hline GT4 & Amuc_1869 & $\begin{array}{l}\text { Glycosyl transferase group } \\
1\end{array}$ & 7.83 & & \\
\hline \multirow[t]{2}{*}{$\mathrm{GH} 2$} & Amuc_0539 & $\begin{array}{l}\text { Glycoside hydrolase family } \\
2 \text { sugar binding }\end{array}$ & 7.76 & & \\
\hline & Amuc_1436 & Malate dehydrogenase & 7.74 & $\begin{array}{c}\text { ko00020;ko006 } \\
\text { 20;ko00630;ko00680 }\end{array}$ & $\begin{array}{l}\text { Citrate Cycle (TCA cycle); } \\
\text { Pyruvate metabolism; } \\
\text { Glycoxylate and } \\
\text { dicarboxylate metabolism; } \\
\text { Methane metabolism }\end{array}$ \\
\hline GH89 & Amuc_1220 & $\begin{array}{l}\text { Alpha-N- } \\
\text { acetylglucosaminidase }\end{array}$ & 7.73 & & \\
\hline GH95 & Amuc_1120 & $\begin{array}{l}\text { Putative uncharacterized } \\
\text { protein }\end{array}$ & 7.72 & ko00511 & Other glycan degradation \\
\hline GH36 & Amuc_0216 & $\begin{array}{l}\text { Putative uncharacterized } \\
\text { protein }\end{array}$ & 7.66 & & \\
\hline \multirow[t]{2}{*}{ GH13 } & Amuc_1751 & $\begin{array}{l}\text { Glycoside hydrolase family } \\
13 \text { domain protein }\end{array}$ & 7.65 & ko00500 & $\begin{array}{l}\text { Starch and sucrose } \\
\text { metabolism }\end{array}$ \\
\hline & Amuc_1543 & Formate acetyltransferase & 7.54 & $\begin{array}{l}\text { ko00620;ko006 } \\
40 ; \text { ko00650 }\end{array}$ & $\begin{array}{l}\text { Pyruvate metabolism; } \\
\text { Propanoate metabolism; } \\
\text { Butanoate metabolism }\end{array}$ \\
\hline GH57 & Amuc_1868 & $\begin{array}{l}\text { Glycoside hydrolase family } \\
57\end{array}$ & 7.42 & ko00500 & $\begin{array}{l}\text { Starch and sucrose } \\
\text { metabolism }\end{array}$ \\
\hline $\begin{array}{c}\text { GH35, } \\
\text { CBM32 }\end{array}$ & Amuc_1686 & Beta-galactosidase & 7.37 & ko00052 & Galactose metabolism \\
\hline $\begin{array}{c}\text { GH110,CBM } \\
51 \\
\end{array}$ & Amuc_0480 & Alpha-1,3-galactosidase B & 6.90 & & \\
\hline GH33 & Amuc_0625 & Exo-alpha-sialidase & 6.89 & ko00511 & Other glycan degradation \\
\hline GH98 & Amuc_1438 & $\begin{array}{l}\text { Glycosyl hydrolase family } \\
98 \text { putative carbohydrate } \\
\text { binding module }\end{array}$ & 6.86 & & \\
\hline GH35 & Amuc_0771 & Beta-galactosidase & 6.79 & ko00052;ko00511 & $\begin{array}{l}\text { Galactose metabolism; } \\
\text { Other glycan degradation }\end{array}$ \\
\hline GH16 & Amuc_0724 & $\begin{array}{l}\text { Glucan endo-1,3-beta-D- } \\
\text { glucosidase }\end{array}$ & 6.73 & & \\
\hline $\mathrm{GH} 33$ & Amuc_1835 & Exo-alpha-sialidase & 6.70 & ko00511 & Other glycan degradation \\
\hline $\begin{array}{c}\text { GH123.CBM } \\
32 \\
\end{array}$ & Amuc_0803 & $\begin{array}{l}\text { Coagulation factor } 5 / 8 \text { type } \\
\text { domain protein }\end{array}$ & 6.66 & & \\
\hline CBM50 & Amuc_0821 & $\begin{array}{l}\text { Peptidoglycan-binding } \\
\text { LysM }\end{array}$ & 6.30 & & \\
\hline GH20 & Amuc_1032 & $\begin{array}{l}\text { Beta-N- } \\
\text { acetylhexosaminidase }\end{array}$ & 6.29 & & \\
\hline CE4 & Amuc_1500 & Polysaccharide deacetylase & 6.27 & & \\
\hline GH95 & Amuc_0186 & $\begin{array}{l}\text { Glycoside hydrolase family } \\
95\end{array}$ & 6.24 & & \\
\hline GH89 & Amuc_0060 & $\begin{array}{l}\text { Alpha-N- } \\
\text { acetylglucosaminidase }\end{array}$ & 6.18 & & \\
\hline GT28 & Amuc_0659 & $\begin{array}{l}\text { UDP-N- } \\
\text { acetylglucosamine--N- } \\
\text { acetylmuramyl- } \\
\text { (pentapeptide) }\end{array}$ & 6.18 & ko00550 & Peptidoglycan biosynthesis \\
\hline
\end{tabular}

Continued 


\begin{tabular}{|c|c|c|c|c|c|}
\hline CAZy & Locus tag & Protein & $\begin{array}{c}\text { Average_LFQ_ } \\
\text { Human Milk }\end{array}$ & KO ID & Pathway \\
\hline & & $\begin{array}{l}\text { pyrophosphoryl- } \\
\text { undecaprenol N- } \\
\text { acetylglucosamine } \\
\text { transferase }\end{array}$ & & & \\
\hline GH77 & Amuc_1621 & 4-alpha-glucanotransferase & 6.14 & ko00500 & $\begin{array}{l}\text { Starch and sucrose } \\
\text { metabolism }\end{array}$ \\
\hline \multirow[t]{4}{*}{ GT51 } & Amuc_2122 & $\begin{array}{l}\text { Glycosyl transferase family } \\
51\end{array}$ & 6.09 & & \\
\hline & Amuc_0756 & $\begin{array}{l}\text { ADP-L-glycero-D-manno- } \\
\text { heptose-6-epimerase }\end{array}$ & 6.01 & ko00540 & $\begin{array}{l}\text { Lipopolysaccharide } \\
\text { biosynthesis }\end{array}$ \\
\hline & Amuc_1880 & $\begin{array}{l}\text { Isocitrate dehydrogenase } \\
\text { [NADP] }\end{array}$ & 5.97 & ko00020;ko00480 & $\begin{array}{l}\text { Citrate Cycle (TCA cycle); } \\
\text { Glutathione metabolism }\end{array}$ \\
\hline & Amuc_0523 & $\mathrm{KpsF} /$ GutQ family protein & 5.91 & ko00540;ko01100 & $\begin{array}{l}\text { Lipopolysaccharide } \\
\text { biosynthesis; Metabolic } \\
\text { pathways }\end{array}$ \\
\hline GH16 & Amuc_2108 & $\begin{array}{l}\text { Glycoside hydrolase family } \\
16\end{array}$ & 5.86 & & \\
\hline GH88 & Amuc_0863 & $\begin{array}{l}\text { Glycosyl hydrolase family } \\
88\end{array}$ & 5.86 & & \\
\hline GH16 & Amuc_0875 & $\begin{array}{l}\text { Glycoside hydrolase family } \\
16\end{array}$ & 5.71 & & \\
\hline GH43 & Amuc_0698 & Beta-glucanase & 5.65 & & \\
\hline GH20 & Amuc_1669 & $\begin{array}{l}\text { Beta-N- } \\
\text { acetylhexosaminidase }\end{array}$ & 5.52 & ko00511;ko00520 & $\begin{array}{l}\text { Other glycan degradation; } \\
\text { Amino sugar and } \\
\text { nucleotide sugar } \\
\text { metabolism }\end{array}$ \\
\hline \multirow[t]{4}{*}{$\mathrm{GH} 27$} & Amuc_1187 & Alpha-galactosidase & 5.47 & ko00052;ko00561 & $\begin{array}{l}\text { Galactose metabolism; } \\
\text { Glycerolipid metabolism }\end{array}$ \\
\hline & Amuc_1572 & $\begin{array}{l}\text { 2-methylcitrate } \\
\text { synthase/citrate synthase II }\end{array}$ & 5.43 & ko00020;ko00630 & $\begin{array}{l}\text { Citrate Cycle (TCA cycle); } \\
\text { Glycoxylate and } \\
\text { dicarboxylate metabolism }\end{array}$ \\
\hline & Amuc_1756 & $\begin{array}{l}\text { Phosphoenolpyruvate- } \\
\text { protein phosphotransferase }\end{array}$ & 5.42 & ko02060 & $\begin{array}{l}\text { Phosphotransferase system } \\
\text { (PTS) }\end{array}$ \\
\hline & Amuc_0369 & $\begin{array}{l}\text { Beta-N- } \\
\text { acetylhexosaminidase }\end{array}$ & 5.41 & ko00511;ko00520 & $\begin{array}{l}\text { Other glycan degradation; } \\
\text { Amino sugar and } \\
\text { nucleotide sugar } \\
\text { metabolism }\end{array}$ \\
\hline \multirow[t]{2}{*}{$\mathrm{GH} 20$} & Amuc_1924 & $\begin{array}{l}\text { Beta-N- } \\
\text { acetylhexosaminidase }\end{array}$ & 5.41 & & \\
\hline & Amuc_1242 & $\begin{array}{l}\text { Inositol-phosphate } \\
\text { phosphatase }\end{array}$ & 5.24 & ko00521;ko00562 & $\begin{array}{l}\text { Streptomycin biosynthesis; } \\
\text { Inositol phosphate } \\
\text { metabolism }\end{array}$ \\
\hline GH29 & Amuc_0010 & Alpha-L-fucosidase & 5.00 & ko00511 & Other glycan degradation \\
\hline GH36 & Amuc_0517 & Raffinose synthase & 5.00 & & \\
\hline GH43 & Amuc_0697 & Beta-glucanase & 5.00 & & \\
\hline GT2 & Amuc_0757 & $\begin{array}{l}\text { Glycosyl transferase family } \\
2\end{array}$ & 5.00 & & \\
\hline GH109 & Amuc_0920 & $\begin{array}{l}\text { Glycosyl hydrolase family } \\
109 \text { protein } 2\end{array}$ & 5.00 & & \\
\hline GH97 & Amuc_1420 & $\begin{array}{l}\text { Putative uncharacterized } \\
\text { protein }\end{array}$ & 5.00 & & \\
\hline \multirow[t]{2}{*}{ GT2 } & Amuc_1582 & $\begin{array}{l}\text { Glycosyl transferase family } \\
2\end{array}$ & 5.00 & & \\
\hline & Amuc_1616 & Polysaccharide deacetylase & 5.00 & & \\
\hline GH13 & Amuc_1637 & $\begin{array}{l}\text { Alpha amylase catalytic } \\
\text { region }\end{array}$ & 5.00 & & \\
\hline GH2, CBM32 & Amuc_1667 & $\begin{array}{l}\text { Glycoside hydrolase family } \\
2 \text { sugar binding }\end{array}$ & 5.00 & & \\
\hline GH20 & Amuc_1815 & $\begin{array}{l}\text { Beta-N- } \\
\text { acetylhexosaminidase }\end{array}$ & 5.00 & & \\
\hline GH20 & Amuc_2018 & $\begin{array}{l}\text { Beta-N- } \\
\text { acetylhexosaminidase }\end{array}$ & 5.00 & $\begin{array}{l}\text { ko00511;ko005 } \\
20 ; \mathrm{ko} 00531\end{array}$ & $\begin{array}{l}\text { Other glycan degradation; } \\
\text { Amino sugar and } \\
\text { nucleotide sugar } \\
\text { metabolism }\end{array}$ \\
\hline
\end{tabular}

Table 1. Abundance of $A$. muciniphila enzymes involved in carbohydrate metabolism with their corresponding KEGG identifier (KO ID). The average of Log10 transformed LFQ values is shown. Colouring is based on abundance from the most abundant (red) to medium abundant (orange) to least abundant (green).

ages from the HMO, LNT (Gal $\beta 1-3 G l c N A c \beta 1-3 G a l \beta 1-4 G l c)$ and lactose (Gal $\beta 1-4 G l c)$. Amuc_0771 showed a $k_{\text {cat }} 4.42 \times 10^{3} \mathrm{~min}^{-1}$ and a $K_{\mathrm{M}} 1,223 \pm 171.7 \mu \mathrm{M}$ against LNT ( $\left.\beta 1-3\right)$ (Table 2). In addition, Amuc_0771 was able to release $711 \mu \mathrm{M}$ of glucose and $936 \mu \mathrm{M}$ of galactose when was incubated in 2,000 $\mu \mathrm{M}$ of lactose overnight (Supplementary Fig. 5). However, the reaction in lactose was slow and therefore we were not able to assess the kinetics of Amuc_0771. The enzyme displayed cleaving capacity for both $\beta 1-3$ and $\beta 1-4$ glycosidic linkages, but with higher substrate specificity towards $\beta 1-3$ linkages. The other $\beta$-galactosidase (Amuc_1686) showed no enzymatic activity against LNT or lactose. E. coli BL21 Rosetta strain harbouring the pCDF1-b empty vector induced with IPTG was used as negative control and it was incubated overnight in $2 \mathrm{mM} \mathrm{LNT}, 2^{\prime}$-FL, lactose and 5 mM LNT2 showing no activity at all, against these substrates (Supplementary Fig. 7). 


\begin{tabular}{|c|c|c|c|c|c|}
\hline & Substrate & $\operatorname{Vmax}\left(\mu \mathrm{M} \min ^{-1}\right)$ & $\mathbf{k}_{\text {cat }}\left(\min ^{-1}\right)$ & $\mathrm{K}_{\mathrm{M}}(\mu \mathrm{M})$ & $\mathbf{k}_{\mathrm{cat}} / \mathrm{K}_{\mathrm{M}}\left(\min ^{-1} \mu \mathrm{M}^{-1}\right)$ \\
\hline \multirow{3}{*}{ a-L-fucosidase } & \multicolumn{5}{|l|}{ Amuc_0010 } \\
\hline & PNP-Fucose & $19.76 \pm 11.30$ & $2.27 \mathrm{E}+04$ & $841.23 \pm 46.72$ & 27.07 \\
\hline & 2'-Fucosyllactose & $25.13 \pm 6.80$ & 152.08 & $1.03 \times 10^{4} \pm 6.98 \times 10^{3}$ & 0.02 \\
\hline \multirow{6}{*}{$\beta$-hexosaminidases } & \multicolumn{5}{|l|}{ Amuc_0369 } \\
\hline & PNP-GlcNAc & $55.64 \pm 2.02$ & $4.02 \times 10^{4}$ & $323.38 \pm 43.64$ & 124.50 \\
\hline & Lacto- $N$-triose II & $982.61 \pm 37.68$ & $1.42 \times 10^{4}$ & $3,980 \pm 210.30$ & 3.56 \\
\hline & \multicolumn{5}{|l|}{ Amuc_2136 } \\
\hline & PNP-GlcNAc & $109.46 \pm 4.22$ & $8.93 \times 10^{4}$ & $714.55 \pm 47.96$ & 125.10 \\
\hline & Lacto- $N$-triose II & $443.75 \pm 47.20$ & $1.45 \times 10^{4}$ & $2,435.82 \pm 289.51$ & 5.95 \\
\hline \multirow{5}{*}{$\beta$-galactosidases } & \multicolumn{5}{|l|}{ Amuc_0771 } \\
\hline & PNP-Galactose & $60.08 \pm 7.02$ & 825.63 & $2,599 \pm 565.27$ & 0.34 \\
\hline & Lacto- $N$-tetraose & $302.08 \pm 53.71$ & $4.42 \times 10^{3}$ & $1,223 \pm 171.70$ & 3.61 \\
\hline & \multicolumn{5}{|l|}{ Amuc_1686 } \\
\hline & PNP-Galactose & $29.34 \pm 3.80$ & $1.63 \times 10^{3}$ & $319.40 \pm 259.30$ & 4.21 \\
\hline
\end{tabular}

Table 2. Kinetic parameters of $\alpha$-L-fucosidase (Amuc_0010), $\beta$-hexosaminidases (Amuc_0369 and Amuc_2136) and $\beta$-galactosidases (Amuc_0771 and Amuc_1686) with synthetic substrates and HMOS.

A. muciniphila expresses mucus-utilisation enzymes to consume human milk oligosaccharides. Akkermansia muciniphila is adept at mucus glycans degradation and we showed in this study that $A$. muciniphila was able also to utilise human milk glycans. Thus, we investigated whether the enzymatic capacity is adapted to the different environmental conditions. Consequently, we compared the protein expression profile between A. muciniphila grown on human milk and grown on mucin.

First, we tested the activity of $A$. muciniphila cell lysates by measuring $\alpha$-fucosidase, $\beta$-galactosidase and sialidase activities from cultures grown in either human milk or mucin. The lysates from mucin- and human milk cultures were incubated with synthetic substrates and both demonstrated fucosidase, $\beta$-galactosidase and sialidase activity. Human milk cell lysates showed significantly higher $\beta$-galactosidase and sialidase activity than in mucin lysates (Fig. 4a,b). Fucosidase activity was similar for both human milk and mucin (Fig. 4c). The cell lysates were also incubated with lactose or 2'-FL. Samples were taken at $0,20 \mathrm{~h}$ and analysed by HPAEC-PAD. The lysates from A. muciniphila grown both on human milk and mucin showed partial degradation of lactose into its constituent monosaccharides (glucose and galactose) and partial degradation of 2'-FL into lactose, glucose, galactose and fucose (Supplementary Fig. 6a-d).

Second, a comparative proteome study identified the enzymes of $A$. muciniphila that are expressed in either human milk or mucus conditions. A total of 832 proteins were detected in both human milk and mucin. Fortysix proteins were significantly more abundant in human milk ( $p$-value $<0.05)$, while 219 proteins more abundant in mucin condition (Supplementary Fig. 7). The rest of the proteins were expressed in similar amounts between the two conditions. We identified 108 proteins that were involved in carbohydrate metabolic process, of which the majority (67\%) was expressed in similar amounts in human milk and mucin (Table 3), while 36 (33\%) were significantly influenced by the environmental conditions (Supplementary Tables 5 and 6 ). When focusing on mucus glycan degradation enzymes, 42 out of the 61 annotated enzymes in the A. muciniphila proteome were detected in both milk and mucin conditions (Table 3 ). The majority (64\%) was expressed in similar amounts in both conditions. Three proteins were significantly more abundant in human milk (Amuc_1755 and Amuc_1033 encoding for sulfatase activity, Amuc_0670 encoding for trypsin-like protein serine protease), and 12 proteins were more abundant in mucin condition (Amuc_1631-Carboxyl terminal protease, Amuc_1220- $\alpha-N$-acetylglucosaminidase, Amuc_0451-Sulfatase, Amuc_0824-Glycoside Hydrolase Family 2, Amuc_1008-Glycoside Hydrolase Family 31, Amuc_1835-Exo-a-sialidase, Amuc_1182-Sulfatase, Amuc_0010- $\alpha$-L-fucosidase, Amuc_0369- $\beta$ - $N$-acetylhexosaminidase, Amuc_1187- $\alpha$-galactosidase, Amuc_1924- $\beta$ - $N$-acetylhexosaminidase, and Amuc_1815- $\beta$ - $N$-acetylhexosaminidase). The majority of the glycan-degrading enzymes were found to be carbohydrate-active enzymes belonging to the glycoside hydrolases (GH) family (Table 3). Finally, human milk conditions showed a higher expression of the pili-associated protein (Amuc_1100), which has been characterised as an outer membrane protein ${ }^{35}$. All proteins of the pili gene cluster (Amuc_1098 - Amuc_1102), were expressed in (Amuc_1099, Amuc_1100, Amuc_1101) in higher levels in human milk, while Amuc_1098 was more abundant on mucin ( $p$-value $<0.05)$. The results indicate that $A$. muciniphila has a highly adapted lifestyle to thrive on complex host-derived glycan structures such as the ones in human milk and the mucus layer, where similar enzymes are used by the organism to degrade either substrate.

\section{Discussion}

This study demonstrates that A. muciniphila can grow on human milk thanks to the expression of a set of HMO degrading enzymes. Human milk fermentation by A. muciniphila resulted in the degradation of fucosylated and sialylated HMOs (Fig. 3). We demonstrated that A. muciniphila GH29 a-fucosidase (Amuc_0010) could cleave the a1-2-linked fucose to galactose. However, the high $K_{\mathrm{M}}$ value obtained during incubation with $2^{\prime}$-FL indicates that this substrate might not be one of the preferred substrates for Amuc_0010. In mucus, fucose is mostly 

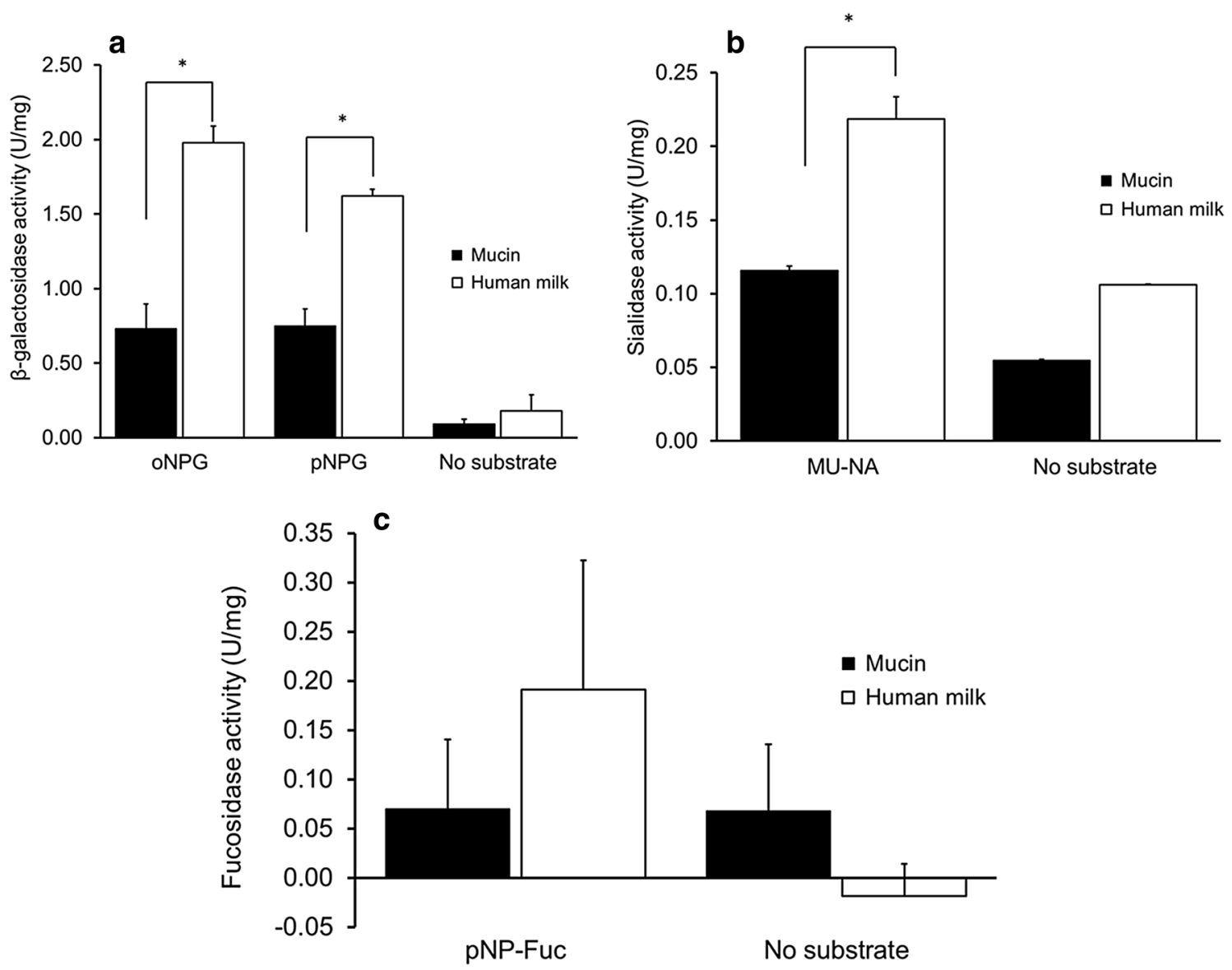

Figure 4. Enzymatic activity of cells lysates of $A$. muciniphila. The activity of (a) $\beta$-galactosidases, (b) sialidases and (c) $\alpha$-fucosidases in cell lysates was tested with $2.5 \mathrm{mM}$ oNPG/pNPG, $2.5 \mathrm{mM}$ MU-NA and $0.5 \mathrm{mM}$ pNPFuc, respectively. One unit $(\mathrm{U})$ is the amount of enzyme that converts $1 \mu$ mole substrate per min.

found linked through a1-6 to the reducing, terminal GlcNAc ${ }^{30}$ in $O$-glycans, indicating that this enzyme from A. muciniphila might prefer mucus glycans structures over glycosidic linkages that are present in HMOs. HMO content differs per person based on the expression of certain glycosyltransferases. For instance, the presence of terminal $\alpha 1-2$ fucosylated HMOs requires a functional $\alpha 1-2$ fucosyltransferase (FUT2), encoded by the secretor gene in humans ${ }^{36,37}$. Interestingly, it was reported that $A$. muciniphila is more abundant in the caesarean-born infants of FUT2 secretor mothers than in the non-secretor mothers ${ }^{38}$. In this study, we showed that A. muciniphila can use fucose from human milk and basal media supplemented with 2'-FL as an energy source resulting in the production of 1,2-propanediol. This agrees with the ability of $A$. muciniphila to use fucose released from mucin. The liberation of 1,2-propanediol could lead to cross-feeding in the gut as previous studies have shown that 1,2-propanediol was utilised by other bacteria in the gastrointestinal tract ${ }^{39-42}$. For instance, Eubacterium hallii and Lactobacillus reuteri were able to utilise 1,2-propanediol derived from the fermentation of fucose and rhamnose to produce propionate ${ }^{39,40}$. In this way, the milk and mucus degrading ability of $A$. muciniphila would support microbial network formation in the early life intestine and the early life mucosal environment in the gut.

A. muciniphila encodes sialidases that could cleave the 3 '-sialyllactose into lactose and neuraminic acid. The activity of $A$. muciniphila against sialylated mucus-glycans has been assessed before ${ }^{43}$. We found that the two exo- $\alpha$-sialidases (Amuc_0625 and Amuc_1835) were present in our proteomics dataset. The release of $\alpha 2-3$ and a2-6-linked sialic acid from sialylated HMOs $3^{\prime}$-SL and $6^{\prime}-\mathrm{SL}^{44}$ are therefore considered to be the result of their activity. Sialic acid resulting from the degradation of $3^{\prime}$-SL could not be further utilised by A. muciniphila, which could be due to the fact that it lacks the Nan cluster $(\mathrm{NanA} / \mathrm{K} / \mathrm{E})$ that is described to be necessary for the sialic acid utilisation in other microorganisms ${ }^{45}$. Both human milk and mucin are rich in terminal sialyl-groups. The sialidase activity of $A$. muciniphila enables the release of sialic acid, however it seems most likely that $A$. muciniphila uses its sialidase activity to reach the sugars that are difficult to attain. At the same time, the released sialic acid could serve as substrate for community members, rather than for $A$. muciniphila itself. This implies a key role for A. muciniphila in the formation of a microbial network in the infant gut stimulating growth of bacteria that can use sialyl-groups and thus increasing diversity. Bifidobacterium breve's growth, for example, is promoted by the sialic acid that is liberated from the degradation of sialyl-oligosaccharides in the gut by Bifidobacterium bifidum ${ }^{46,47}$. Additionally, Ruminococcus gnavus ATCC 29149 that is present in the digestive tract of humans encodes a complete Nan cluster for the sialic acid consumption ${ }^{48}$. It has been also reported that Bacteroides fragilis was able to metabolise the released sialic acid in the gut via an alternative pathway (nanLET) ${ }^{49}$. To further support 


\begin{tabular}{|c|c|c|c|c|}
\hline Locus tag & Protein & Log10 Fold change & $\mathrm{p}$-value & CAZy Family \\
\hline Amuc_1815 & Beta-N-acetylhexosaminidase & -1.74 & 0.00 & $\mathrm{GH} 20$ \\
\hline Amuc_1924 & Beta- $\mathrm{N}$-acetylhexosaminidase & -1.72 & 0.01 & $\mathrm{GH} 20$ \\
\hline Amuc_1500 & Polysaccharide deacetylase & -1.53 & 0.08 & CE4 \\
\hline Amuc_1187 & Alpha-galactosidase & -1.48 & 0.02 & $\mathrm{GH} 27$ \\
\hline Amuc_0369 & Beta-N-acetylhexosaminidase & -1.22 & 0.03 & $\mathrm{GH} 20$ \\
\hline Amuc_0863 & Glycosyl hydrolase family 88 & -1.19 & 0.06 & GH105 \\
\hline Amuc_1616 & Polysaccharide deacetylase & -1.14 & 0.02 & CE4 \\
\hline Amuc_0010 & Alpha-L-fucosidase & -1.13 & 0.03 & GH29 \\
\hline Amuc_1686 & Beta-galactosidase & -1.01 & 0.25 & $\begin{array}{l}\text { GH35, } \\
\text { CBM32 }\end{array}$ \\
\hline Amuc_1667 & Glycoside hydrolase family 2 sugar binding & -0.90 & 0.13 & $\mathrm{GH} 2$ \\
\hline Amuc_1032 & Beta-N-acetylhexosaminidase & -0.81 & 0.32 & $\mathrm{GH} 20$ \\
\hline Amuc_1669 & Beta- $\mathrm{N}$-acetylhexosaminidase & -0.66 & 0.35 & $\mathrm{GH} 20$ \\
\hline Amuc_1835 & Exo-alpha-sialidase & -0.57 & 0.01 & $\mathrm{GH} 33$ \\
\hline Amuc_0060 & Alpha- $\mathrm{N}$-acetylglucosaminidase & -0.57 & 0.21 & GH89 \\
\hline Amuc_1438 & $\begin{array}{l}\text { Glycosyl hydrolase family } 98 \text { putative } \\
\text { carbohydrate binding module }\end{array}$ & -0.54 & 0.43 & CBM51 \\
\hline Amuc_0186 & Glycoside hydrolase family 95 & -0.51 & 0.27 & GH95 \\
\hline Amuc_0771 & Beta-galactosidase & -0.42 & 0.52 & GH35 \\
\hline Amuc_1637 & Alpha amylase catalytic region & -0.38 & 0.36 & $\mathrm{GH} 13$ \\
\hline Amuc_0697 & Beta-glucanase & -0.37 & 0.36 & GH43 \\
\hline Amuc_2018 & Beta- $\mathrm{N}$-acetylhexosaminidase & -0.35 & 0.36 & $\mathrm{GH} 20$ \\
\hline Amuc_1008 & Glycoside hydrolase family 31 & -0.34 & 0.01 & GH31 \\
\hline Amuc_0824 & Glycoside hydrolase family 2 TIM barrel & -0.32 & 0.01 & $\mathrm{GH} 2$ \\
\hline Amuc_1220 & Alpha- $\mathrm{N}$-acetylglucosaminidase & -0.29 & 0.05 & GH89 \\
\hline Amuc_0724 & Glucan endo-1,3-beta-D-glucosidase & -0.18 & 0.77 & GH16 \\
\hline Amuc_0290 & Glycoside hydrolase family 2 sugar binding & -0.14 & 0.12 & $\mathrm{GH} 2$ \\
\hline Amuc_0625 & Exo-alpha-sialidase & -0.13 & 0.85 & GH33 \\
\hline Amuc_2136 & Glycoside hydrolase, family 20 , catalytic core & -0.07 & 0.23 & $\mathrm{GH} 20$ \\
\hline Amuc_0539 & Glycoside hydrolase family 2 sugar binding & -0.03 & 0.79 & $\mathrm{GH} 2$ \\
\hline Amuc_1868 & Glycoside hydrolase family 57 & 0.00 & 0.97 & GH57 \\
\hline Amuc_0698 & Beta-glucanase & 0.01 & 0.98 & $\mathrm{GH} 43$ \\
\hline Amuc_0392 & Coagulation factor $5 / 8$ type domain protein & 0.03 & 0.54 & GH29 \\
\hline Amuc_0235 & Alpha-glucan phosphorylase & 0.09 & 0.46 & GT35 \\
\hline Amuc_0875 & Glycoside hydrolase family 16 & 0.19 & 0.73 & GH16 \\
\hline Amuc_2108 & Glycoside hydrolase family 16 & 0.86 & 0.13 & GH16 \\
\hline Amuc_1880 & Isocitrate dehydrogenase [NADP] & -1.52 & 0.03 & - \\
\hline Amuc_1480 & $\begin{array}{l}\text { Peptidase S11 D-alanyl-D-alanine } \\
\text { carboxypeptidase } 1\end{array}$ & -1.25 & 0.13 & - \\
\hline Amuc_1756 & $\begin{array}{l}\text { Phosphoenolpyruvate-protein } \\
\text { phosphotransferase }\end{array}$ & -1.18 & 0.03 & - \\
\hline Amuc_0756 & $\begin{array}{l}\text { ADP-L-glycero-D-manno-heptose-6- } \\
\text { epimerase }\end{array}$ & -1.02 & 0.13 & - \\
\hline Amuc_0391 & Peptidase M23 & -0.93 & 0.16 & - \\
\hline Amuc_1182 & Sulfatase & -0.90 & 0.03 & - \\
\hline Amuc_1543 & Formate acetyltransferase & -0.83 & 0.00 & - \\
\hline Amuc_0523 & KpsF/GutQ family protein & -0.63 & 0.27 & - \\
\hline Amuc_1436 & Malate dehydrogenase & -0.58 & 0.03 & - \\
\hline Amuc_0155 & $\begin{array}{l}\text { Phosphoglucomutase/phosphomannomutase } \\
\text { alpha/beta/alpha domain I }\end{array}$ & -0.46 & 0.04 & - \\
\hline Amuc_0451 & Sulfatase & -0.29 & 0.04 & - \\
\hline Amuc_1631 & Carboxyl-terminal protease & -0.26 & 0.00 & - \\
\hline Amuc_0491 & Sulfatase & -0.24 & 0.36 & - \\
\hline Amuc_0953 & Sulfatase & -0.19 & 0.09 & - \\
\hline Amuc_2040 & Oligopeptidase A & -0.18 & 0.36 & - \\
\hline Amuc_1106 & Peptidase M24 & -0.15 & 0.50 & - \\
\hline Amuc_1074 & Sulfatase & -0.11 & 0.39 & - \\
\hline Amuc_1572 & 2-methylcitrate synthase/citrate synthase II & -0.07 & 0.92 & - \\
\hline Amuc_0121 & Sulfatase & 0.17 & 0.20 & - \\
\hline Amuc_1033 & Sulfatase & 0.24 & 0.02 & - \\
\hline Amuc_1242 & Inositol-phosphate phosphatase & 0.24 & 0.17 & - \\
\hline Amuc_0670 & $\begin{array}{l}\text { Trypsin-like protein serine protease typically } \\
\text { periplasmic contain C-terminal PDZ domain- } \\
\text { like protein }\end{array}$ & 0.29 & 0.01 & - \\
\hline Amuc_0465 & Peptidase M23 & 0.73 & 0.10 & - \\
\hline Amuc 1755 & Sulfatase & 1.02 & 0.01 & - \\
\hline
\end{tabular}

Table 3. A. muciniphila's saccharolytic enzymes. Locus tags in grey indicate the enzymes that are predicted to be in mucin degradation with their corresponding CAZy Family group. Positive values (Log10 Fold change) indicate higher abundance in human milk than in mucin condition. P-values less than 0.05 are shown in with light blue colour. 
the cross-feeding properties of $A$. muciniphila, it has been observed before that $A$. muciniphila is stimulated by the presence of the butyrate producer Anaerostipes caccae when grown on mucin. Indeed, A. muciniphila when co-cultured with $A$. caccae upregulates mucin-degrading genes that can play a role in the degradation of oligosaccharide chains consisting of monomeric sugars such as GalNAc, GlcNAc, mannose, galactose, fucose and sialic acid ${ }^{50}$.

In the proteome data, we further identified two $\beta$-galactosidases (Amuc_0771, Amuc_1686) of A. muciniphila, that showed similar expression between human milk and mucin cultures. The recombinantly-expressed protein Amuc_0771 displayed activity on lactose by releasing galactose and glucose. However, the rate of hydrolysis of the reaction was slow and we were unable to determine the kinetics of this enzyme on lactose. This finding is consistent with that of Kosciow et al. who observed that Amuc_0771 exhibited low relative hydrolytic activity against $\beta 1-4$ linked galactose to glucose (lactose) and $\beta 1-4$ linked galactose to $N$-acetyl-D-glucosamine (LacNAc) ${ }^{51}$. Guo et al., recently characterised the enzymatic activity of an $A$. muciniphila GH35 $\beta$-galactosidase, Am0874. In this study, a different tool was used for annotation A. muciniphila's genes that is not in any other common genome or proteome database (ncbi.nlm.nih.gov, genome.jp/keg, uniport.org,). When we aligned the protein sequences from both $\beta$-galactosidases NCBI we found a 100\% identity between Amuc_0771 and Am0874. Based on their data we can confirm that this enzyme can hydrolyse glycosidic bonds in synthetic substrates and $N$-glycans. They pointed out that the enzyme showed higher efficiency of cleaving $\beta 1-3$ and $\beta 1-6$ than $\beta 1-4$-linked galactose. Interestingly, they found that Am0874 had lower cleaving capacity when galactose was linked to GlcNAc in $\beta 1-4$ configuration compared to galactose linked in $\beta 1-3$-configuration GalNAc ${ }^{52}$. In our results this $\beta$-galactosidase (Amuc_0771) exhibited higher hydrolysis against $\beta 1$-3-linked galactose (LNT) than $\beta 1-4$ configuration (lactose). The other $\beta$-galactosidase (Amuc_1686) that we studied, showed no hydrolysing capacity against LNT or lactose. The activity of Amuc_1686 has been characterised in another study where it is reported that the enzyme exhibits no activity against lactose either, but it showed preference over Galacto- $N$-biose (Gal $\beta 1-3 \mathrm{GalNAc})^{53}$. In the same study, it is mentioned that Amuc_1686 is able to cleave only the $\beta 1$-3-linked galactose to GalNAc and not the $\beta 1$-3-linked galactose to GlcNAc. Their findings might explain the reason why Amuc_1686 was not active against the $\beta 1$-3-linked galactose to GlcNAc (LNT) in our experiments. A. muciniphila's $\beta$-galactosidases are responsible for the liberation of the terminal galactose linked to milk's glycan structures. The free galactose is consumed further by the action of a galactokinase (Amuc_0969). Surprisingly, closer analysis of the proteome data highlighted that A. muciniphila produced Amuc_0969 in higher amounts than Amuc_0097, indicating that galactose continued being utilised by A. muciniphila compared to glucose (Supplementary Table 4).

In the absence of glycoproteins from mucus A. muciniphila has an essential need for GlcNAc ${ }^{54}$. In case of growth on human milk GlcNAc could be released by $\beta$-acetylhexosaminidases. Wang et al., recently described two A. muciniphila GH20 $\beta$-acetylhexosaminidases (Am2301 and Am2446) that were able to cleave the terminal GlcNAc off the $N$ - and $O$-glycans, confirming its exo-activity as glycoside hydrolases ${ }^{55}$. Our biochemical experiment on the purified $\beta$-acetylhexosaminidases (Amuc_0369 and Amuc_2136) revealed that both enzymes were able to hydrolyse only the terminal $\beta 1-3$ linked GlcNAc to lactose (LNT2) that results to the liberation of lactose molecule and not the GlcNAc that is located inside the HMO structure (LNT).

A. muciniphila grown on human milk led to the production of a significant amount of succinate $(\sim 10 \mathrm{mM})$. A. muciniphila uses the succinate pathway to produce propionate in the gut, as has been described before ${ }^{56}$. Recently, it has been demonstrated that A. muciniphila is dependent on the presence of vitamin B12 as a cofactor of Methylmalonyl-CoA synthase in order to convert succinate to propionate ${ }^{50,57}$. A. muciniphila grown on human milk expresses all the necessary enzymes to successfully convert succinate to propionate (Methylmalonyl-CoA mutase; Amuc_1984, Amuc_1983 and Methylmalonyl-CoA epimerase; Amuc_0200). It is described that in human milk vitamin B12 can be tightly bound to haptocorrin, and the concentration varies depending on the diet of the mother, especially on the intake of animal products ${ }^{58}$. An explanation why succinate is not converted to propionate in human milk in our experiment could be that A. muciniphila is not efficient in using the B12 present in human milk.

Akkermansia muciniphila grown on human milk shows significant higher abundance of the pili-protein $($ Amuc_1100 $)(p \text {-value }=0.02,1.29 \text {-fold change })^{59}$. This outer membrane pili-like protein plays an important role in immune regulation and enhancement of trans-epithelial resistance. Recently, it has been demonstrated that Amuc_1100 is able to improve gut barrier and restrain the high-fat-diet-induced obesity in mice ${ }^{60}$. Therefore, expression of this protein in the infant gut might also contribute to immune maturation and gut health in early life.

Interestingly, the proteome analysis showed high abundance of seven sulfatases functioning as sulfate ester hydrolases. Four of these expressed sulfatases (Amuc_0451, Amuc_1033, Amuc_1182, Amuc_1755) were significantly higher expressed in human milk. It has not been reported so far that HMos could have sulfate residues attached to their glycan structure like in $O$-glycans of mucin. However, it has been described that human milk can contain more than $100 \mu \mathrm{mol} / \mathrm{L}$ of sulfate esters ${ }^{61}$. These sulfate esters are part of the glycosaminoglycans (GAGs). GAGs are present in human milk $(416 \mathrm{mg} / \mathrm{L})$ and are highly sulfated linear polysaccharides constituted by disaccharidic units where the sugar unit is made up of an $N$-acteylhexosamine (GalNAc or GlcNAc) ${ }^{62}$. The most abundant GAGs found in human milk are chondroitin sulfate (CS) $(231 \mathrm{mg} / \mathrm{L})$ and heparin (Hep) (173 mg/L). Therefore, it is possible that $A$. muciniphila deploys its sulfatases for the hydrolysis of the sulfuric esters that are present in human milk glycosaminoglycans.

In this study, it is shown that $A$. muciniphila can grow on human milk and is able to degrade HMOs by using its glycan-degrading enzymes. These glycan-degrading enzymes hydrolyse the HMOs extracellularly into monoand disaccharides and then the liberated sugars are imported in the cell by transporters ${ }^{34}$. These findings allow us to propose a model for the utilisation of 2'-fucosyllactose, 3 '-siallylactose, lacto- $N$-tetraose, lacto- $N$-triose II and lactose by $A$. muciniphila (Fig. 5). The results of the study suggest that $A$. muciniphila is able to survive in early life environment by consuming oligosaccharides coming either from the breast milk or infant formulae. 


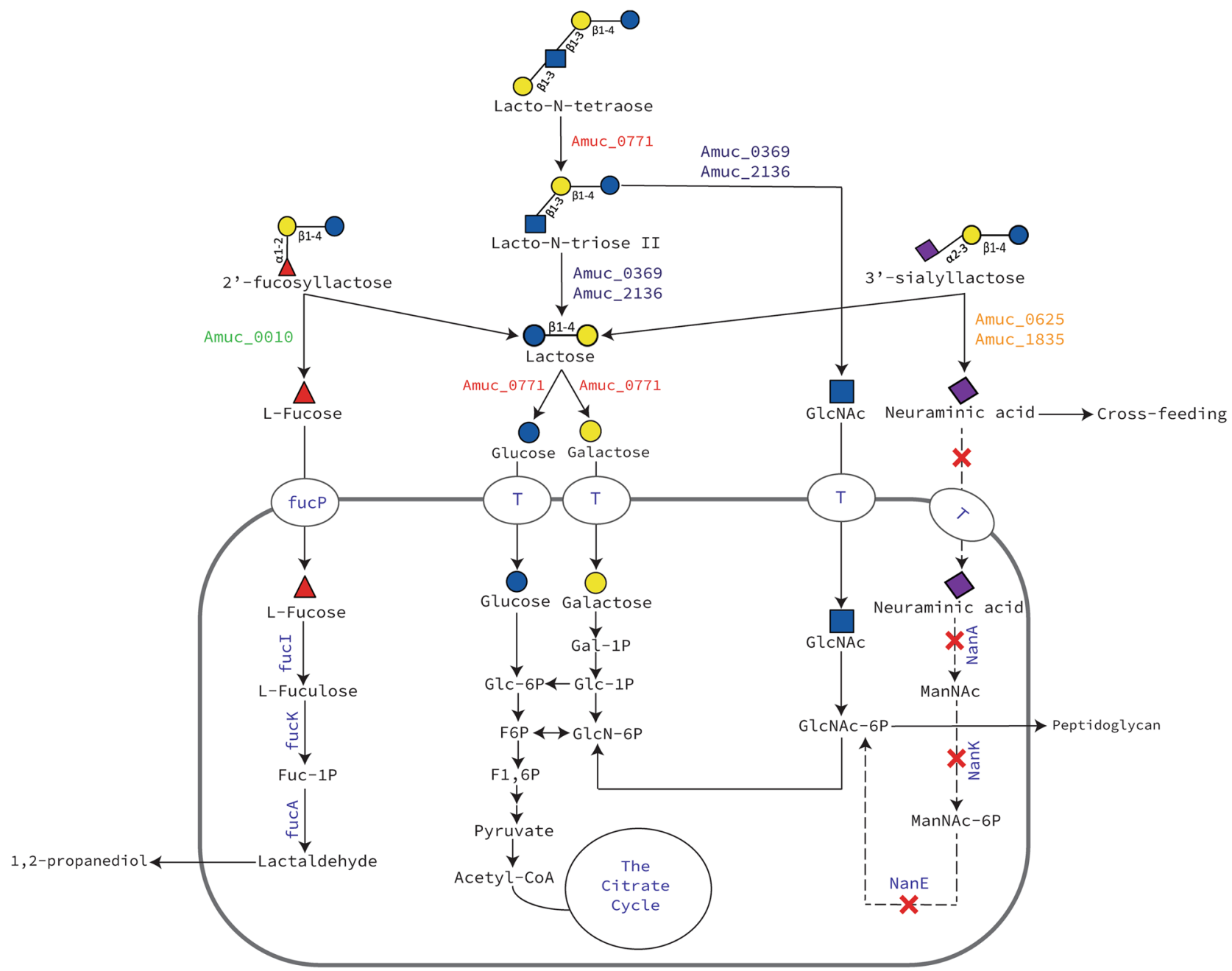

Figure 5. Schematic representation of the proposed pathway for the metabolism of pure $2^{\prime}$-fucosyllactose, $3^{\prime}$-sialyllactose, lacto- $N$-tetraose, lacto- $N$-triose II and lactose by $A$. muciniphila. The proteins in green colour represent $\alpha$-fucosidases, in orange represent sialidases, in red represent $\beta$-galactosidases and in blue represent $\beta$ - $N$-acetylhexosaminidases. fuc $\mathrm{L}_{\mathrm{L}}$-fucose transporter, $T$ putative substrate transporter.

This might provide beneficial effects during the initial early life colonisation of A. muciniphila before it reaches its natural niche, the outer mucosal layer. Furthermore, the insufficient degradation of HMOs by A. muciniphila liberates simpler glycan structures and metabolites, which then become accessible to other beneficial bacteria. The milk environment also activated the expression of A. muciniphila outer membrane protein Amuc_1100 which could benefit the infant immune system ${ }^{63,64}$. Human milk carries its microbiota to the infant's intestine facilitating early life colonisation. Development of a healthy gut microbiota from the beginning of life with glycan-degrading microbes could be associated with health in later life by guiding the development of the immune system and protecting against pathogens ${ }^{65,66}$. As such, A. muciniphila might be one of the key members of the early life guiding healthy microbiota and immune development.

\section{Material and methods}

Bacterial growth conditions. Akkermansia muciniphila $\mathrm{Muc}^{\mathrm{T}}$ (ATCC BAA-835) was grown in basal medium as described previously ${ }^{2}$. The medium was supplemented with either hog gastric mucin $(0.5 \% \mathrm{w} / \mathrm{v}$ Type III, Sigma-Aldrich, St. Louis, MO, USA), which was purified by ethanol precipitation as described previously ${ }^{67}$, human milk ( $10 \% \mathrm{v} / \mathrm{v}), 2^{\prime}$-fucosyllactose $\left(2^{\prime}\right.$-FL, $10 \mathrm{mM}$, purity $\left.>90 \%\right)$ or $3^{\prime}$-sialyllactose (3'-SL, $10 \mathrm{mM}$, purity $>90 \%$ ). The growth conditions containing HMOs (i.e. 2'-FL and $3^{\prime} \mathrm{SL}$ ) were supplemented with $25 \mathrm{mM} N$-acetylglucosamine (GlcNAc) as nitrogen source for A. muciniphila (Sigma-Aldrich). The bottles containing human milk and HMOs were further supplemented with L-Proline and L-Threonine (Sigma-Aldrich) (6 g/L). All the anaerobic bottles were supplemented with $1 \% \mathrm{v} / \mathrm{v}$ of $\mathrm{CaCl}_{2}$ and vitamin mixture as described previously ${ }^{68}$. Human breast milk was collected under sterile conditions from a healthy donor (approximately 3-6 months post-partum) and stored at $-20^{\circ} \mathrm{C}$ until use. Incubations were completed in serum bottles sealed with butyl rubber stoppers at $37^{\circ} \mathrm{C}$ under anaerobic conditions provided by a gas phase of $182 \mathrm{kPa}(1.5 \mathrm{~atm}) \mathrm{N}_{2} / \mathrm{CO}_{2} \mathrm{~T}$. The bacterial growth on mucin by measuring the optical density at $600 \mathrm{~nm}$ and quantitative Polymerase Chain Reac- 
tion (qPCR). The optical density of the cultures of $A$. muciniphila grown in human milk could not be determined due to the high turbidity of the milk. Therefore, bacterial numbers were solely measured by qPCR.

Quantitative real-time PCR (qPCR). The abundance of A. muciniphila in human milk and mucin was determined by qPCR as described previously ${ }^{10}$. Cells $(1 \mathrm{~mL})$ were harvested at $21,000 \times g$ for $15 \mathrm{~min}$. DNA extractions were performed using the MasterPure ${ }^{\text {rs }}$ Gram Positive DNA Purification Kit (Epicentre, Lucigen, USA). DNA concentrations were measured fluorometrically (Qubit dsDNA BR assay, Invitrogen) and adjusted to $1 \mathrm{ng} / \mu \mathrm{L}$ prior to use as the template in qPCR. Primers targeting the $16 \mathrm{~S}$ rRNA gene of $A$. muciniphila (AM1 5'-CAGCACGTGAAGGTGGGGAC-3' and AM2 5'-CCTTGCGGTTGGCTTCAGAT-3'; 327 bp ${ }^{10}$ ) were used for quantification. A standard curve was prepared with nine standard concentrations from $10^{0}$ to $10^{8}$ gene copies/ $\mu \mathrm{L}$. qPCR was performed in triplicate with iQ SYBR green supermix (Bio-Rad, USA) in a total volume of 10 $\mu \mathrm{L}$ prepared with primers at $500 \mathrm{nM}$ in 384-wells plates with the wells sealed with optical sealing tape. Amplification was performed with an iCycler (Bio-rad): one cycle of $95^{\circ} \mathrm{C}$ for $10 \mathrm{~min} ; 40$ cycles of $95^{\circ} \mathrm{C}$ for $15 \mathrm{~s}, 60^{\circ}$ $\mathrm{C}$ for $20 \mathrm{~s}$, and $72^{\circ} \mathrm{C}$ for $30 \mathrm{~s} \mathrm{each}$; one cycle of $95^{\circ} \mathrm{C}$ for $1 \mathrm{~min}$; and a stepwise increase of temperature from 60 to $95^{\circ} \mathrm{C}$ (at $0.5^{\circ} \mathrm{C}$ per $5 \mathrm{~s}$ ) to obtain melt curve data. Data were analysed using Bio-Rad CFX Manager 3.0. The copy number was corrected for the DNA concentration and for the number of 16S rRNA genes encoded in $A$. muciniphila's genome.

Human milk oligosaccharide extraction. HMOs were recovered from $1 \mathrm{~mL}$ aliquots of $A$. muciniphila grown in $10 \% \mathrm{v} / \mathrm{v}$ human milk cultures as described before ${ }^{69}$. An internal standard of 1,5- $\alpha$-L-arabinopentaose (Megazyme, Ireland) was added, at the volume of $10 \mu \mathrm{L}$ per sample to minimize pipetting error, to reach a final concentration of $0.01 \mathrm{mmol} / \mathrm{L}$. The solution was diluted 1:1 with ultrapure water and centrifuged at $4,000 \times g$ for $15 \mathrm{~min}$ at $4{ }^{\circ} \mathrm{C}$. The supernatant was filtered through $0.2 \mu \mathrm{m}$ syringe filter followed by subsequent centrifugation with a pre-washed ultra-filter (Amicon Ultra 0.5 Ultracel Membrane $3 \mathrm{kDa}$ device, Merck Milipore, USA) at $14,000 \times g$ for $1 \mathrm{~h}$ at room temperature. Finally, the filtrate was vortexed and stored at $-20^{\circ} \mathrm{C}$.

Electrospray ionisation liquid chromatography mass spectrometry (LC-ESI-MS ${ }^{2}$ ) analysis. HMOs were identified and quantified with LC-ESI-MS ${ }^{269}$. This method allows the study of distinct HMO structures more in particular their monosaccharide sequence, glycosidic linkage and the molecular conformation. Thereby the HMOs isobaric isomers such as Lacto- $N$-fucopentaose (LNFP) I, II, III and V could be distinguished as described by Mank et al. ${ }^{69}$. We used the latter approach with adaptations. Micro LC-ESI-MS ${ }^{2}$ analysis was performed on a 1,200/1,260 series HPLC stack (Agilent, Waldbronn, Germany) consisting of solvent tray, degasser, binary pump, autosampler and DAD detector coupled to a 3,200 Qtrap mass spectrometer (ABSciex, USA). After extraction of HMOs, $2.5 \mu \mathrm{L}$ of this extract was injected into the LC-MS system. Oligosaccharides were separated by means of a $2.1 \times 30 \mathrm{~mm}$ Hypercab porous graphitized carbon (PGC) column with a $2.1 \times 10 \mathrm{~mm}$ PGC pre-column (Thermo Scientific, USA) using a water-methanol gradient for $30 \mathrm{~min}$, and $2 \mathrm{~min}$ equilibration. Solvent A consisted of $0.3 \%$ ammonium hydroxide solution (28-30\%, Sigma-Aldrich, St. Louis, Missouri United States) in water and solvent B of $0.3 \%$ ammonium hydroxide solution in $95 \%$ methanol (all v/v). Pre-equilibration was performed using $97.5 \%$ solvent A. The gradient started with $97.5 \%$ solvent A for 0.5 min, decreased to $60 \%$ in $12.5 \mathrm{~min}$ and decreased to $40 \%$ in $3 \mathrm{~min}$, where it was kept for $4 \mathrm{~min}$. In a next segment, solvent A decreased in $0.5 \mathrm{~min}$ to $2.5 \%$ where it was kept for $3 \mathrm{~min}$. In $0.5 \mathrm{~min}$, solvent $\mathrm{A}$ increased to $97.5 \%$ for re-equilibration of $6 \mathrm{~min}$. Eluent flow was $400 \mu \mathrm{L} / \mathrm{min}$ and the columns were kept at $45^{\circ} \mathrm{C}$. The LC-effluent was infused online into the mass spectrometer and individual HMO structures were analysed semi-quantitatively by multiple reaction monitoring (MRM) in negative ion mode. Specific MRM transitions for neutral HMOs up to pentaoses and acidic HMOs up to trioses were included. The spray voltage was $-4500 \mathrm{~V}$, the declustering potential and collision energy were optimized to individual compounds measured. A segmented method was used to obtain higher sensitivity. Each MRM-transition was measured for $70 \mathrm{~ms}$. The instrument was calibrated with polypropylene glycol (PPG) according the instruction of the manufacturer.

Protein extraction from $\boldsymbol{A}$. muciniphila cultures. Akkermansia muciniphila was grown in basal medium supplemented with $0.5 \%$ purified mucin or $10 \%$ human milk (4 biological replicates). After 15 and $48 \mathrm{~h}$ incubation at $37^{\circ} \mathrm{C}$, cells $(2 \mathrm{~mL})$ were pelleted at $4,816 \times g$ for $30 \mathrm{~min}$ at $4{ }^{\circ} \mathrm{C}$, re-suspended in $1 \mathrm{~mL} \mathrm{PBS}$, washed twice $\left(21,130 \times g\right.$ at $\left.4{ }^{\circ} \mathrm{C}\right)$, and finally re-suspended in $500 \mu \mathrm{L}$ lysis buffer $(100 \mathrm{mM}$ Tris $\mathrm{HCl}, \mathrm{pH} 8.0,4 \%$ (w/v) SDS, $7.7 \mathrm{mg} / \mathrm{mL}$ Dithiotreitol [DTT]). Cells were lysed by sonication (four pulses of $20 \mathrm{~s}$ with $30 \mathrm{~s}$ rest on ice) with an amplitude of $20-30 \%$ on ice using an MS-72 probe, followed by centrifugation at $21,130 \times g$ for $30 \mathrm{~min}$ at $4{ }^{\circ} \mathrm{C}$. Qubit ${ }^{\circledR}$ Protein Assay Kit (Life technologies, Oregon, USA) was used according to the manufacturer's instructions to determine the protein content of cell extracts. Protein samples $(15 \mathrm{~h}$ for mucin and $48 \mathrm{~h}$ for human milk samples) $(40 \mu \mathrm{g})$ were loaded on a Bolt $4-12 \%$ Bis-Tris Plus separation gel (Invitrogen, Life Technologies, USA) using the XCell Surelock Mini-Cell (Novex, Life Technologies, USA). The electrophoresis procedure was according to the manufacturer's instructions. Gels were stained overnight using QC Colloidal Coomassie Blue G250 stain (Bio-rad Laboratories, USA).

In-gel digestion identification and relative quantification of proteins from $A$. muciniphila cell extracts. Each of the used gel lanes was cut into three slices to increase the number of identified proteins. Slices were further processed to pieces of about $1 \mathrm{~mm}^{2}$ and put in $1.5 \mathrm{~mL}$ low binding tubes (Eppendorf) prior to their reduction, alkylation, and trypsin digestion, as described previously ${ }^{70}$. The supernatant obtained was used for LC-MS/MS analysis. Samples were measured by nLC-MS/MS with a Proxeon EASY nLC and a LTQOrbitrap XL mass spectrometer as previously described ${ }^{71,72}$. LC-MS data analysis was performed as described 
previously ${ }^{70,73,74}$ with false discovery rates (FDRs) set to 0.01 on peptide and protein level, and additional result filtering (minimally two peptides necessary for protein identification of which at least one is unique and at least one is unmodified). Any remaining hits against the reversed database as well as all human proteins were removed. To analyse the abundance of proteins in the fractions, their label-free quantification (LFQ) intensities were compared ${ }^{75}$. Non-existing LFQ intensity values due to not enough quantified peptides were substituted with a value slightly lower than the lowest LFQ intensity value measured. The normal logarithm was taken from protein LFQ MS1 intensities as obtained from MaxQuant. Relative protein quantitation of sample to control was done with Perseus ${ }^{76}$ by applying a two sample T-test using the "LFQ intensity" columns obtained with FDR set to 0.01 and S0 set to 1 . nLC-MSMS system quality was checked with PTXQC ${ }^{77}$ using the MaxQuant result files. The mass spectrometry proteomics data have been deposited to the ProteomeXchange Consortium via the $\mathrm{PRIDE}^{78}$ partner repository with the dataset identifier PXD011357. All the A. muciniphila proteins differentially expressed between milk and mucin conditions are listed in Supplementary Tables 5 and 6.

Cloning, expression and purification of selected A. muciniphila glycoside hydrolases. The selected proteins coded by the genes with locus tags Amuc_0010 (57.51 kDa), Amuc_0369 (72.02 kDa), Amuc_0771 $(70.53 \mathrm{kDa})$, Amuc_1686 $(85.71 \mathrm{kDa})$, and Amuc_2136 $(81.59 \mathrm{kDa})$ without their signal peptides were cloned into the pCDF-1b vector, introducing a $6 x$ His-tag at the C-terminus. The genes of interest and the plasmid backbone were amplified by PCR with gene-specific primers, using Q5 DNA polymerase (New England BioLabs, USA) (Supplementary Table 1). The amplified genes and vector were being assembled with NEBuilder HiFi DNA Assembly Master Mix (NEB BioLabs, USA) according to manufacturer's instructions. $E$. coli DH5-aplha competent cells were transformed using $5 \mu \mathrm{L}$ of assembly reaction and sequences were verified by DNA sequencing by Eurofins (Ebersberg, Germany). E. coli BL21 Rosetta competent cells were transformed with the recombinant plasmid harbouring the genes of interest. The recombinant cells were grown to an $\mathrm{OD}_{600}$ between 0.5 and 0.6 in $250 \mathrm{~mL}$ Lysogeny-Broth (LB) supplemented with $50 \mu \mathrm{g} / \mathrm{mL}$ spectinomycin and $25 \mu \mathrm{g} /$ $\mathrm{mL}$ chloramphenicol. Then, they were induced with $1 \mathrm{mM}$ isopropyl $\beta$-D-1-thiogalactopyranoside (IPTG) at $22^{\circ} \mathrm{C}$ for $16 \mathrm{~h}$. The cells were harvested by centrifugation at 6,000 $\times \mathrm{g}$ for $20 \mathrm{~min}$ and re-suspended in $15 \mathrm{~mL}$ of lysis buffer. Cells were lysed by sonication on ice (1 s pulse with $2 \mathrm{~s}$ rest for $10 \mathrm{~min}$, amplitude of 20-25\%) using a MS-72 microtip (Bandelin, Germany). The lysate was cleared by centrifugation at $120,000 \times g$ for $1 \mathrm{~h}$ at $4{ }^{\circ} \mathrm{C}$. The proteins were His-tag purified using $\mathrm{Ni}^{2+}$-nitrilotriacetate $(\mathrm{Ni}-\mathrm{NTA})$ agarose affinity columns $(500 \mu \mathrm{L}$ bed volume, Qiagen) equilibrated with binding buffer. Samples were loaded, followed by $2 \mathrm{~mL}$ of binding buffer and $2 \times 500 \mu \mathrm{L}$ plus $1 \mathrm{~mL}$ of elution buffer. Purity of the enzymes was checked by SDS-Page (4-10\% polyacrylamide gel) (Supplementary Fig. 2) and pure samples were concentrated using 50-kDa MWCO Amicon Ultra-15 Centrifugal Filter Units (Merck, Germany) with storage buffer. Protein content was measured using the Qubit Protein Assay (manufacturer's protocol) and fluorometer (DeNovix, USA). pCDF-1b empty vector was cloned, expressed and purified as it is described above. The empty vector was used as negative control in all the enzymatic assays.

Activity assays and kinetics. The purified enzymes were incubated with different substrates in McIlvaine buffer solution adjusted to the optimum $\mathrm{pH}$ of each enzyme at $37^{\circ} \mathrm{C}$. To quantify $\alpha$-fucosidase, $\beta$-galactosidase and $\beta$-acetylhexosaminidase activity on synthetic substrates, 4 -nitrophenyl-a-L-fucopyranoside (pNP- $\alpha$-L-Fuc), 4-nitrophenyl-b-D-galactopyranoside (pNPG) and 4-nitrophenyl 2-acetamido-2-deoxy-b-D-glucopyranoside (GlcNAc- $\beta$-pNP) were used respectively. The enzymes were incubated with substrate concentrations ranging from 0 to $5 \mathrm{mM}$ in McIlvaine buffer. At intervals of $2.5 \mathrm{~min}$, samples were taken and added to $2.5 \times$ volume of glycine buffer ( $\mathrm{pH}$ 9.6) to stop the reaction. Absorbance was monitored at $405 \mathrm{~nm}$ and quantified using a standard curve of 4-Nitrophenol ( $\mathrm{pNP}$ ). To determine the optimal $\mathrm{pH}$ of each enzyme, the assay was carried out in McIlvaine buffer with $\mathrm{pH}$ values ranging from 5.0 to 8.2 and a substrate concentration of $\sim 3$ times the $\mathrm{K}_{\mathrm{M}}$ as determined at the initial $\mathrm{pH}$. Next, the aforementioned assays with $0-5 \mathrm{mM}$ substrate were repeated at the optimal $\mathrm{pH}$. For incubations of $\beta$-galactosidases and hexosaminidases with lactose and LNT, the assays were performed in a similar way, but the products were monitored by HPAEC-PAD. The sugars were separated by HPAEC with $10 \mathrm{mM} \mathrm{NaOH}$ at $0.5 \mathrm{~mL} / \mathrm{min}$ on a CarboPac PA20 protected with a guard column and detected using PAD on a Dionex ICS5000 system (Thermo Scientific). The column was cleaned for 10 min with $200 \mathrm{mM}$ $\mathrm{NaOH}$ and re-equilibrated with $10 \mathrm{mM} \mathrm{NaOH}$. Standards of galactose and glucose in different concentrations were used to quantify the results. For incubations of the a-fucosidase with $2^{\prime}$-FL, reactions were performed in a similar way, but the fucose release was measured directly (without adding glycine buffer first) by $\alpha$-L-fucose kit (Megazyme, Ireland) based on a fucose dehydrogenase-coupled method ${ }^{79}$. Reactions without enzyme and with only the purified plasmid incubated in both synthetic and human milk derived sugars were served as negative controls. Kinetic data of the enzymes were obtained from triplicate experiments, and the kinetic parameters were calculated by fitting the initial raw data to the Michaelis-Menten equation using linear regression analysis, and the error bars (SD).

Cell lysate activity. Enzymatic activity of A. muciniphila cell lysates was tested with colorimetric substrates as described previously ${ }^{80}$. The following substrate/enzyme combinations were used: 4-nitrophenyl- $\alpha-$ L-fucopyranoside/fucosidase (pNP-Fuc), 4-nitrophenyl- $\beta$-D-galactopyranoside (pNPG) and 2-nitrophenyl$\beta$-D-galactopyranoside (ONPG)/ $\beta$-galactosidase, and 2 -(4-methylumbelliferyl)- $\alpha$-D- $N$-acetylneuraminic acid (MU-NA)/sialidase. Reactions were performed in a final volume $20 \mu \mathrm{L}$, using $0.5-2.5 \mathrm{mM}$ substrate and $\sim 1 \mu \mathrm{g} / \mathrm{mL}$ enzyme in $0.05 \mathrm{M}$ citrate buffer $\mathrm{pH} 6.0$ (fucosidase, sialidase) or $0.25 \mathrm{M}$ phosphate buffer, $\mathrm{pH} 7.0$ ( $\beta$-galactosidase). After $1 \mathrm{~h}$ of incubation at $37^{\circ} \mathrm{C}$, reactions were stopped by adding $50 \mu \mathrm{L} 0.5$ glycine buffer, $\mathrm{pH}$ 9.6. Absorbance was read at $405 \mathrm{~nm}$ (pNPG and pNP-Fuc) or $420 \mathrm{~nm}$ (oNPG) and fluorescence intensity was 
measured at $\lambda_{\mathrm{ex}} 390 \mathrm{~nm}, \lambda_{\mathrm{em}} 460 \mathrm{~nm}$ on a 96-well plate reader (Biotek, USA). Activity is expressed in units (U), in which one unit is the amount of enzyme that converts $1 \mu$ mole substrate per minute. To test fucosidase and galactosidase activity of cell lysates in $2^{\prime}$-FL and lactose, $\sim 10 \mu \mathrm{g} / \mathrm{mL}$ of each enzyme was incubated with $1 \mathrm{mM}$ lactose and $1 \mathrm{mM}$ of $2^{\prime}$-FL in $0.05 \mathrm{mM}$ citrate buffer, pH 6.0 in a final volume of $1 \mathrm{~mL}$, shaking at $300 \mathrm{rpm}$. Reactions of aliquots at different time points were stopped by adding $2.5 \times$ the volume of $0.5 \mathrm{M}$ glycine buffer, pH 9.6. The reaction was monitored by HPAEC-PAD as it was described previously.

High-performance liquid chromatography. For fermentation product analysis, samples were obtained at different time points of the incubation period. Crotonate was used as the internal standard and the external standards were lactate, formate, acetate, propionate, butyrate, succinate, 1,2-propanediol, lactose, $N$-acetyl-glucosamine (GlcNAc), N-acetyl-galactosamine (GalNAc), 2'-fucosyllactose (2'-FL), 3'-sialyllactose (3'-SL), glucose, galactose, fucose and sialic acid. Substrate conversion and product formation were measured with Thermo Scientific Spectrasystem high-performance liquid chromatography (HPLC) system equipped with a Varina Metacarb $67 \mathrm{H} 300 \times 6.5 \mathrm{~mm}$ column kept at $45^{\circ} \mathrm{C}$ and running $0.0005 \mathrm{mM}$ sulfuric acid as eluent. The eluent had a flow of $0.5 \mathrm{~mL} / \mathrm{min}$ and metabolites were detected by determining the refractive index (RI-150) and identified by using standards of pure compounds as described previously ${ }^{81}$.

Statistical analysis. Statistics were performed using student's t-test and corrected for multiple testing using False Discovery Rate (FDR). Data are presented as mean \pm standard deviation (SD), unless stated otherwise. $P$-values below 0.05 were considered significant.

Ethical consideration. The usage and analysis of human milk samples described in this study were performed with written consent by the donor.

Received: 3 April 2020; Accepted: 10 July 2020

Published online: 31 August 2020

\section{References}

1. Derrien, M. et al. Mucin-bacterial interactions in the human oral cavity and digestive tract. Gut Microbes 1, 254-268. https://doi. org/10.4161/gmic.1.4.12778 (2010).

2. Derrien, M. Akkermansia muciniphila gen. nov., sp. Nov., a human intestinal mucin-degrading bacterium. Int. J. Syst. Evol. Microbiol. 54, 1469-1476. https://doi.org/10.1099/ijs.0.02873-0 (2004).

3. Dao, M. C. et al. Akkermansia muciniphila and improved metabolic health during a dietary intervention in obesity: Relationship with gut microbiome richness and ecology. Gut 65, 426-436. https://doi.org/10.1136/gutjnl-2014-308778 (2016).

4. Karlsson, C. L. J. et al. The microbiota of the gut in preschool children with normal and excessive body weight. Obesity 20, 2257-2261. https://doi.org/10.1038/oby.2012.110 (2012).

5. Zhang, X. et al. Human gut microbiota changes reveal the progression of glucose intolerance. PLoS ONE 8, e71108. https://doi. org/10.1371/journal.pone.0071108 (2013).

6. Png, C. W. et al. Mucolytic bacteria with increased prevalence in IBD mucosa augment in vitro utilization of mucin by other bacteria. Am. J. Gastroenterol. 105, 2420-2428. https://doi.org/10.1038/ajg.2010.281 (2010).

7. Rajilić-Stojanović, M., Shanahan, F., Guarner, F. \& De Vos, W. M. Phylogenetic analysis of dysbiosis in ulcerative colitis during remission. Inflamm. Bowel Dis. 19, 481-488. https://doi.org/10.1097/MIB.0b013e31827fec6d (2013).

8. Swidsinski, A. et al. Acute appendicitis is characterised by local invasion with Fusobacterium nucleatum/necrophorum. Gut 60, 34-40. https://doi.org/10.1136/gut.2009.191320 (2011).

9. Derrien, M., Collado, M. C., Ben-Amor, K., Salminen, S. \& de Vos, W. M. The mucin degrader Akkermansia muciniphila is an abundant resident of the human intestinal tract. Appl. Environ. Microbiol. 74, 1646-1648. https://doi.org/10.1128/AEM.01226-07 (2008).

10. Collado, M. C., Derrien, M., Isolauri, E., de Vos, W. M. \& Salminen, S. Intestinal integrity and Akkermansia muciniphila, a mucindegrading member of the intestinal microbiota present in infants, adults, and the elderly. Appl. Environ. Microbiol. 73, 7767-7770. https://doi.org/10.1128/AEM.01477-07 (2007).

11. Collado, M. C., Laitinen, K., Salminen, S. \& Isolauri, E. Maternal weight and excessive weight gain during pregnancy modify the immunomodulatory potential of breast milk. Pediatr. Res. 72, 77-85. https://doi.org/10.1038/pr.2012.42 (2012).

12. Aakko, J. et al. Human milk oligosaccharide categories define the microbiota composition in human colostrum. Benef. Microbes 8, 563-567. https://doi.org/10.3920/BM2016.0185 (2017).

13. Urbaniak, C. et al. Microbiota of human breast tissue. Appl. Environ. Microbiol. 80, 3007-3014. https://doi.org/10.1128/AEM.00242 $-14(2014)$.

14. Azad, M. B. et al. Gut microbiota of healthy Canadian infants: Profiles by mode of delivery and infant diet at 4 months. Can. Med. Assoc. J. 185, 385-394. https://doi.org/10.1503/cmaj.121189 (2013).

15. Bergström, A. et al. Establishment of intestinal microbiota during early life: A longitudinal. Explor. Study Large Cohort Danish Infants. https://doi.org/10.1128/AEM.00342-14 (2014).

16. Bäckhed, F. et al. Dynamics and stabilization of the human gut microbiome during the first year of life. Cell Host Microbe 17, 690-703. https://doi.org/10.1016/j.chom.2015.04.004 (2015).

17. Neville, M. C. et al. Lactation and neonatal nutrition: Defining and refining the critical questions. J. Mammary Gland Biol. Neoplasia 17, 167-188. https://doi.org/10.1007/s10911-012-9261-5 (2012).

18. Koropatkin, N. M., Cameron, E. A. \& Martens, E. C. How glycan metabolism shapes the human gut microbiota. Nat. Rev. Microbiol. 10, 323-335. https://doi.org/10.1038/nrmicro2746 (2012).

19. Ninonuevo, M. R. et al. A strategy for annotating the human milk glycome. J. Agric. Food Chem. 54, 7471-7480. https://doi. org $/ 10.1021 / \mathrm{jf0615810} \mathrm{(2006).}$

20. Ruiz-Palacios, G. M., Cervantes, L. E., Ramos, P., Chavez-Munguia, B. \& Newburg, D. S. Campylobacter jejuni binds intestinal $\mathrm{H}(\mathrm{O})$ antigen (Fucal, 2Gal $1,4 \mathrm{GlcNAc}$ ), and Fucosyloligosaccharides of human milk inhibit its binding and infection. J. Biol. Chem. 278, 14112-14120. https://doi.org/10.1074/jbc.M207744200 (2003). 
21. Stahl, B. et al. Oligosaccharides from human milk as revealed by matrix-assisted laser desorption/ionization mass spectrometry. Anal. Biochem. 223, 218-226. https://doi.org/10.1006/abio.1994.1577 (1994).

22. Urashima, T., Hirabayashi, J., Sato, S. \& Kobata, A. Human milk oligosaccharides as essential tools for basic and application studies on galectins. Trends Glycosci. Glycotechnol. 30, 51-65. https://doi.org/10.4052/tigg.1734.1SE (2018).

23. Ayechu-Muruzabal, V. et al. Diversity of human milk oligosaccharides and effects on early life immune development. Front. Pediatr. 6, 239. https://doi.org/10.3389/fped.2018.00239 (2018).

24. Zivkovic, A. M., German, J. B., Lebrilla, C. B. \& Mills, D. A. Human milk glycobiome and its impact on the infant gastrointestinal microbiota. Proc. Natl. Acad. Sci. 108, 4653-4658. https://doi.org/10.1073/pnas.1000083107 (2011).

25. Wu, S., Tao, N., German, J. B., Grimm, R. \& Lebrilla, C. B. Development of an annotated library of neutral human milk oligosaccharides. J. Proteome Res. 9, 4138-4151. https://doi.org/10.1021/pr100362f (2010).

26. Weiss, G. A. \& Hennet, T. The role of milk sialyllactose in intestinal bacterial colonization. Adv. Nutr. 3, 483S-488S. https://doi. org/10.3945/an.111.001651 (2012).

27. Bode, L. Human milk oligosaccharides: Every baby needs a sugar mama. Glycobiology 22, 1147-1162. https://doi.org/10.1093/ glycob/cws074 (2012).

28. Vandenplas, Y. et al. Human milk oligosaccharides: $2^{\prime}$-fucosyllactose (2'-FL) and lacto- $N$-neotetraose (LNnT) in infant formula. Nutrients 10, 1161. https://doi.org/10.3390/nu10091161 (2018).

29. Garrido, D., Dallas, D. C. \& Mills, D. A. Consumption of human milk glycoconjugates by infant-associated bifidobacteria: Mechanisms and implications. Microbiology (United Kingdom) 159, 649-664. https://doi.org/10.1099/mic.0.064113-0 (2013).

30. Tailford, L. E., Crost, E. H., Kavanaugh, D. \& Juge, N. Mucin glycan foraging in the human gut microbiome. Front. Genet. 6, 81. https://doi.org/10.3389/fgene.2015.00081 (2015).

31. Bansil, R. \& Turner, B. S. Mucin structure, aggregation, physiological functions and biomedical applications. Curr. Opin. Colloid Interface Sci. 11, 164-170. https://doi.org/10.1016/j.cocis.2005.11.001 (2006).

32. Abodinar, A., Tømmeraas, K., Ronander, E., Smith, A. M. \& Morris, G. A. The physicochemical characterisation of pepsin degraded pig gastric mucin. Int. J. Biol. Macromol. 87, 281-286. https://doi.org/10.1016/J.IJBIOMAC.2016.02.062 (2016).

33. Johansson, M. E. V. et al. The inner of the two Muc2 mucin-dependent mucus layers in colon is devoid of bacteria. Proc. Natl. Acad. Sci. 105, 15064-15069. https://doi.org/10.1073/pnas.0803124105 (2008).

34. Ottman, N. et al. Genome-scale model and omics analysis of metabolic capacities of Akkermansia muciniphila reveal a preferential mucin-degrading lifestyle. Appl. Environ. Microbiol. 83, e01014-e1017. https://doi.org/10.1128/AEM.01014-17 (2017).

35. Ottman, N. et al. Characterization of outer membrane proteome of akkermansia muciniphila reveals sets of novel proteins exposed to the human intestine. Front. Microbiol. 7, 1157. https://doi.org/10.3389/fmicb.2016.01157 (2016).

36. Moran, A. P., Gupta, A. \& Joshi, L. Sweet-talk: Role of host glycosylation in bacterial pathogenesis of the gastrointestinal tract. Gut 60, 1412-1425. https://doi.org/10.1136/gut.2010.212704 (2011).

37. Kumazaki, T. \& Yoshida, A. Biochemical evidence that secretor gene, Se, is a structural gene encoding a specific fucosyltransferase. Proc. Natl. Acad. Sci. 81, 4193-4197. https://doi.org/10.1073/pnas.81.13.4193 (1984).

38. Korpela, K. et al. Fucosylated oligosaccharides in mother's milk alleviate the effects of caesarean birth on infant gut microbiota. Sci. Rep. 8, 13757. https://doi.org/10.1038/s41598-018-32037-6 (2018).

39. Engels, C., Ruscheweyh, H.-J., Beerenwinkel, N., Lacroix, C. \& Schwab, C. The common gut microbe Eubacterium hallii also contributes to intestinal propionate formation. Front. Microbiol. 7, 1-12. https://doi.org/10.3389/fmicb.2016.00713 (2016).

40. Amin, H. M., Hashem, A. M., Ashour, M. S. \& Hatti-Kaul, R. 1,2 Propanediol utilization by Lactobacillus reuteri DSM 20016, role in bioconversion of glycerol to 1,3 propanediol, 3-hydroxypropionaldehyde and 3-hydroxypropionic acid. J. Genet. Eng. Biotechnol. 11, 53-59. https://doi.org/10.1016/j.jgeb.2012.12.002 (2013).

41. Staib, L. \& Fuchs, T. M. Regulation of fucose and 1,2-propanediol utilization by Salmonella enterica serovar Typhimurium. Front. Microbiol. 6, 1-11. https://doi.org/10.3389/fmicb.2015.01116 (2015).

42. Faber, F. et al. Respiration of microbiota-derived 1,2-propanediol drives salmonella expansion during colitis. PLOS Pathog. 13, e1006129. https://doi.org/10.1371/journal.ppat.1006129 (2017).

43. Huang, K. et al. Biochemical characterisation of the neuraminidase pool of the human gut symbiont Akkermansia muciniphila. Carbohydr. Res. 415, 60-65. https://doi.org/10.1016/j.carres.2015.08.001 (2015).

44. Tailford, L. E. et al. Discovery of intramolecular trans-sialidases in human gut microbiota suggests novel mechanisms of mucosal adaptation. Nat. Commun. 6, 7624. https://doi.org/10.1038/ncomms8624 (2015).

45. van Passel, M. W. J. et al. The genome of Akkermansia muciniphila, a dedicated intestinal mucin degrader, and its use in exploring intestinal metagenomes. PLoS ONE 6, e16876. https://doi.org/10.1371/journal.pone.0016876 (2011).

46. Nishiyama, K. et al. Bifidobacterium bifidum extracellular sialidase enhances adhesion to the mucosal surface and supports carbohydrate assimilation. MBio https://doi.org/10.1128/mBio.00928-17 (2017).

47. Nishiyama, K. et al. Two extracellular sialidases from Bifidobacterium bifidum promote the degradation of sialyl-oligosaccharides and support the growth of Bifidobacterium breve. Anaerobe 52, 22-28. https://doi.org/10.1016/j.anaerobe.2018.05.007 (2018).

48. Crost, E. H. et al. The mucin-degradation strategy of Ruminococcus gnavus: The importance of intramolecular trans-sialidases. Gut Microbes 7, 302-312. https://doi.org/10.1080/19490976.2016.1186334 (2016).

49. Brigham, C. et al. Sialic acid ( $N$-acetyl neuraminic acid) utilization by Bacteroides fragilis requires a novel $N$-acetyl mannosamine epimerase. J. Bacteriol. 191, 3629-3638. https://doi.org/10.1128/JB.00811-08 (2009).

50. Chia, L. W. et al. Deciphering the trophic interaction between Akkermansia muciniphila and the butyrogenic gut commensal Anaerostipes caccae using a metatranscriptomic approach. Antonie Van Leeuwenhoek 111, 859-873. https://doi.org/10.1007/s1048 2-018-1040-x (2018).

51. Kosciow, K. \& Deppenmeier, U. Characterization of three novel $\beta$-galactosidases from Akkermansia muciniphila involved in mucin degradation. Int. J. Biol. Macromol. https://doi.org/10.1016/j.ijbiomac.2020.01.246 (2020).

52. Guo, B.-S. et al. Cloning, purification and biochemical characterisation of a GH35 beta-1,3/beta-1,6-galactosidase from the mucindegrading gut bacterium Akkermansia muciniphila. Glycoconj. J. 35, 255-263. https://doi.org/10.1007/s10719-018-9824-9 (2018).

53. Kosciow, K. \& Deppenmeier, U. Characterization of a phospholipid-regulated $\beta$-galactosidase from Akkermansia muciniphila involved in mucin degradation. Microbiologyopen https://doi.org/10.1002/mbo3.796 (2019).

54. van der Ark, K. C. H. et al. Model-driven design of a minimal medium for Akkermansia muciniphila confirms mucus adaptation. Microb. Biotechnol. 11, 476-485. https://doi.org/10.1111/1751-7915.13033 (2018).

55. Wang, M. et al. Cloning, purification and biochemical characterization of two $\beta$ - $N$-acetylhexosaminidases from the mucin-degrading gut bacterium Akkermansia muciniphila. Carbohydr. Res. 457, 1-7. https://doi.org/10.1016/j.carres.2017.12.007 (2018).

56. Reichardt, N. et al. Phylogenetic distribution of three pathways for propionate production within the human gut microbiota. ISME J. 8, 1323-1335. https://doi.org/10.1038/ismej.2014.14 (2014).

57. Belzer, C. et al. Microbial metabolic networks at the mucus layer lead to diet-independent butyrate and vitamin B 12 production by intestinal symbionts. MBio 8, 1-14. https://doi.org/10.1128/mBio.00770-17 (2017).

58. Allen, L. H. B vitamins in breast milk: Relative importance of maternal status and intake, and effects on infant status and function. Adv. Nutr. 3, 362-369. https://doi.org/10.3945/an.111.001172 (2012).

59. Ottman, N. et al. Pili-like proteins of Akkermansia muciniphila modulate host immune responses and gut barrier function. PLoS ONE 12, e0173004. https://doi.org/10.1371/journal.pone.0173004 (2017). 
60. Plovier, H. et al. A purified membrane protein from Akkermansia muciniphila or the pasteurized bacterium improves metabolism in obese and diabetic mice. Nat. Med. 23, 107-113. https://doi.org/10.1038/nm.4236 (2017).

61. McPhee, M. D., Atkinson, S. A. \& Cole, D. E. C. Quantitation of free sulfate and total sulfoesters in human breast milk by ion chromatography. J. Chromatogr. B Biomed. Sci. Appl. 527, 41-50. https://doi.org/10.1016/S0378-4347(00)82081-2 (1990).

62. Coppa, G. V. et al. Composition and structure elucidation of human milk glycosaminoglycans. Glycobiology 21, 295-303. https:// doi.org/10.1093/glycob/cwq164 (2011).

63. Tseng, T.-T., Tyler, B. M. \& Setubal, J. C. Protein secretion systems in bacterial-host associations, and their description in the gene ontology. BMC Microbiol. 9, S2. https://doi.org/10.1186/1471-2180-9-S1-S2 (2009).

64. Galdiero, S. et al. Microbe-host interactions: Structure and role of gram-negative bacterial porins. Curr. Protein Pept. Sci. 13, 843-854. https://doi.org/10.2174/138920312804871120 (2012).

65. Brugman, S., Perdijk, O., van Neerven, R. J. J. \& Savelkoul, H. F. J. Mucosal immune development in early life: Setting the stage. Arch. Immunol. Ther. Exp. (Warsz) 63, 251-268. https://doi.org/10.1007/s00005-015-0329-y (2015).

66. Duerr, C. U. \& Hornef, M. W. The mammalian intestinal epithelium as integral player in the establishment and maintenance of host-microbial homeostasis. Semin. Immunol. 24, 25-35. https://doi.org/10.1016/j.smim.2011.11.002 (2012).

67. Hoskins, L. C. et al. Mucin degradation in human colon ecosystems isolation and properties of fecal strains that degrade ABH blood group antigens and oligosaccharides from mucin glycoproteins. J. Clin. Invest 75, 944-953 (1985).

68. Stams, A. J., Van Dijk, J. B., Dijkema, C. \& Plugge, C. M. Growth of syntrophic propionate-oxidizing bacteria with fumarate in the absence of methanogenic bacteria. Appl. Environ. Microbiol. 59, 1114-1119 (1993).

69. Mank, M., Welsch, P., Heck, A. J. R. \& Stahl, B. Label-free targeted LC-ESI-MS2 analysis of human milk oligosaccharides (HMOS) and related human milk groups with enhanced structural selectivity. Anal. Bioanal. Chem. 411, 231-250. https://doi.org/10.1007/ s00216-018-1434-7 (2019).

70. Rupakula, A. et al. The restricted metabolism of the obligate organohalide respiring bacterium Dehalobacter restrictus: Lessons from tiered functional genomics. Philos. Trans. R. Soc. B Biol. Sci. 368, 20120325. https://doi.org/10.1098/rstb.2012.0325 (2013).

71. Lu, J. et al. Filter-aided sample preparation with dimethyl labeling to identify and quantify milk fat globule membrane proteins. $J$. Proteomics 75, 34-43. https://doi.org/10.1016/j.jprot.2011.07.031 (2011).

72. Wendrich, J. R., Boeren, S., Möller, B. K., Weijers, D. \& De Rybel, B. In vivo identification of plant protein complexes using IP-MS/MS. in Methods in Molecular Biology vol. 1497 147-158 (Humana Press, New York, NY, 2017). https://doi. org/10.1007/978-1-4939-6469-7_14.

73. Hubner, N. C. et al. Quantitative proteomics combined with BAC TransgeneOmics reveals in vivo protein interactions. J. Cell Biol. 189, 739-754. https://doi.org/10.1083/jcb.200911091 (2010).

74. Smaczniak, C. et al. Proteomics-based identification of low-abundance signaling and regulatory protein complexes in native plant tissues. Nat. Protocols https://doi.org/10.1038/nprot.2012.129 (2012).

75. Cox, J. et al. Accurate proteome-wide label-free quantification by delayed normalization and maximal peptide ratio extraction. Termed MaxLFQ. Mol. Cell. Proteomics 13, 2513-2526. https://doi.org/10.1074/mcp.M113.031591 (2014).

76. Tyanova, S. et al. The Perseus computational platform for comprehensive analysis of (prote)omics data. Nat. Methods 13, 731-740. https://doi.org/10.1038/nmeth.3901 (2016).

77. Bielow, C., Mastrobuoni, G. \& Kempa, S. Proteomics quality control: Quality control software for MaxQuant results. J. Proteome Res. 15, 777-787. https://doi.org/10.1021/acs.jproteome.5b00780 (2016).

78. Vizcaíno, J. A. et al. 2016 update of the PRIDE database and its related tools. Nucleic Acids Res. 44, D447-D456. https://doi. org/10.1093/nar/gkv1145 (2016).

79. Morris, J. B. Enzymatic assay for subnanomole amounts of l-fucose. Anal. Biochem. 121, 129-134. https://doi.org/10.1016/00032697(82)90565-6 (1982).

80. Rosendale, D. I. et al. Characterizing kiwifruit carbohydrate utilization in vitro and its consequences for human faecal microbiota. J. Proteome Res. 11, 5863-5875. https://doi.org/10.1021/pr300646m (2012).

81. van Gelder, A. H., Aydin, R., Alves, M. M. \& Stams, A. J. M. 1,3-Propanediol production from glycerol by a newly isolated Trichococcus strain. Microb. Biotechnol. 5, 573-578. https://doi.org/10.1111/j.1751-7915.2011.00318.x (2012).

\section{Acknowledgements}

This work was funded by the EU Joint Programming Initiative-A Healthy Diet for a Healthy Life (JPI HDHL, https://www.healthydietforhealthylife.eu/) and Netherlands Organization for Scientific Research (Spinoza Award and SIAM Gravity Grant 024.002.002). Ioannis Mougiakos, Despoina Trasanidou, Prarthana Mohanraju, and Constantinos Patinios are acknowledged for their important input on cloning, expression and purification of the targeted proteins. Furthermore, Hanne Tytgat is acknowledged for her constructive comments.

\section{Author contributions}

I.K., C.B. wrote the manuscript, analysed the data and designed the experiments. I.K. performed all the experiments with the assistance of J.E., N.O. and S.A. J.E. assisted in protein expression and purification, in the enzymatic assays and contributed to writing the manuscript. J.T.K. cloned some of the proteins used in the primary enzymatic assays (data are not shown). B.B. and M.M. quantified the HMOs in breast milk samples with ESILC-MS. S.B. quantified the protein content of the human milk and mucin samples with nLC-MS/MS. J.K. and W.M.V. supervised the work. C.B. conceived and supervised this work and contributed to analysing the results and writing the manuscript. The manuscript has been read and approved for submission by all the named authors.

\section{Competing interests}

The contributing authors Prof. Dr. Jan Knol, Marko Mank and Bernadet Blijenberg are financially supported by Danone Nutricia Research. The remaining authors declares no competing interests.

\section{Additional information}

Supplementary information is available for this paper at https://doi.org/10.1038/s41598-020-71113-8.

Correspondence and requests for materials should be addressed to C.B.

Reprints and permissions information is available at www.nature.com/reprints.

Publisher's note Springer Nature remains neutral with regard to jurisdictional claims in published maps and institutional affiliations. 
(c) (i) Open Access This article is licensed under a Creative Commons Attribution 4.0 International cc) License, which permits use, sharing, adaptation, distribution and reproduction in any medium or format, as long as you give appropriate credit to the original author(s) and the source, provide a link to the Creative Commons license, and indicate if changes were made. The images or other third party material in this article are included in the article's Creative Commons license, unless indicated otherwise in a credit line to the material. If material is not included in the article's Creative Commons license and your intended use is not permitted by statutory regulation or exceeds the permitted use, you will need to obtain permission directly from the copyright holder. To view a copy of this license, visit http://creativecommons.org/licenses/by/4.0/.

(C) The Author(s) 2020 